Alma Mater Studiorum - Università di Bologna DEPARTMENT OF ECONOMICS

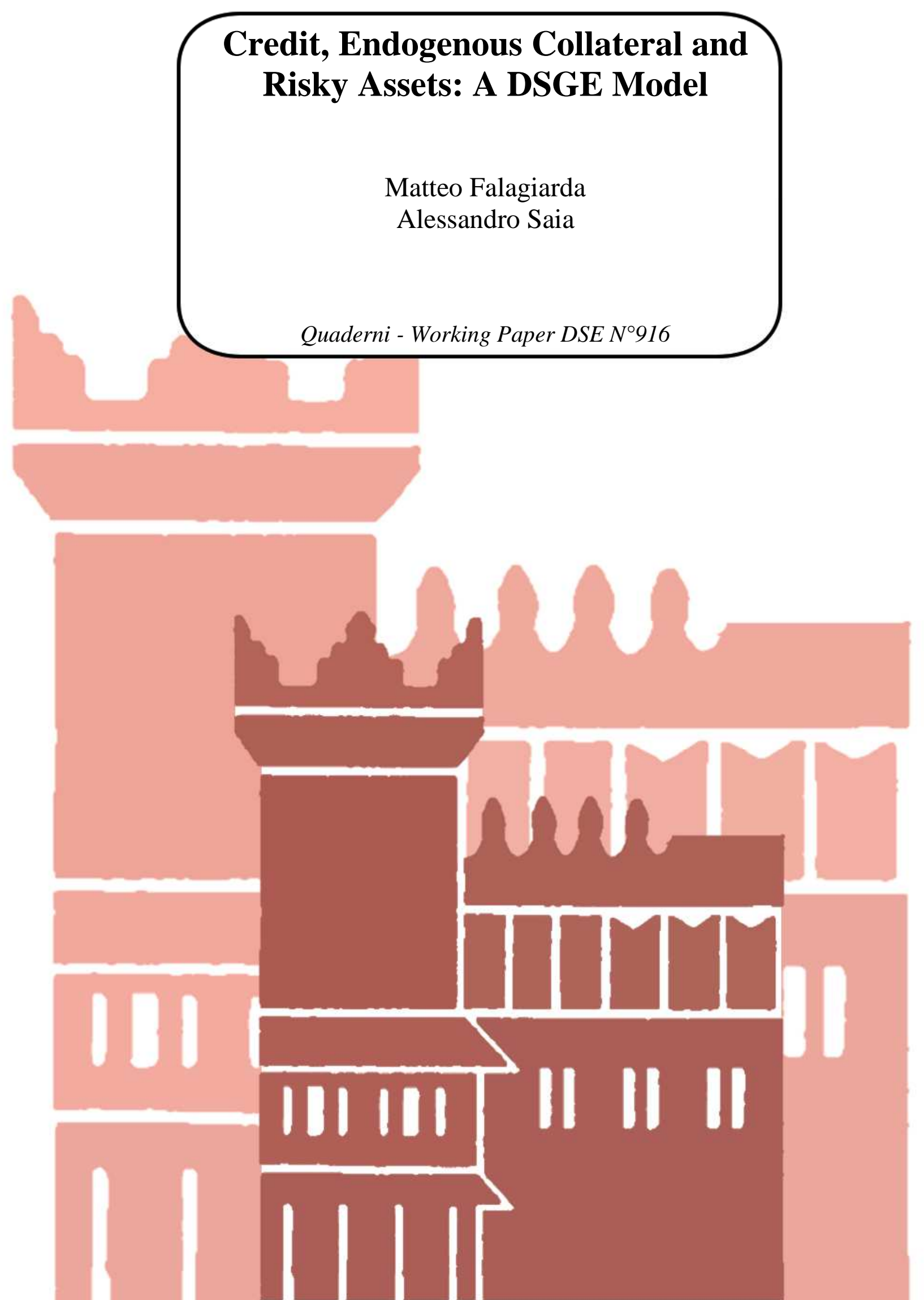




\title{
Credit, Endogenous Collateral and Risky Assets: A DSGE Model
}

\author{
Matteo Falagiarda* Alessandro Saia ${ }^{\dagger}$
}

December 18, 2013

\begin{abstract}
This paper proposes a new Dynamic Stochastic General Equilibrium (DSGE) model with credit frictions and a banking sector, which endogenizes loan-to-value (LTV) ratios of households and banks by expressing them as a function of systemic and idiosyncratic proxies for risk. Moreover, the model features endogenous balance sheet choices and a novel formulation of the targeted leverage ratio, in which assets are risk-weighted by risk-sensitivity measures. The results highlighted in this paper are important along two dimensions. First of all, the presence of endogenous LTV ratios exacerbates the procyclicality of lending conditions. Second, the model contributes to deeper understand the role of prudential regulatory frameworks in affecting business cycle fluctuations and in restoring macroeconomic and financial stability. The results suggest that when the economy is severely stressed by shocks originating in the financial sector, prudential regimes such as Basel II and Basel III are capable of downsizing substantially aggregate volatility, with Basel III found to be significantly more effective than Basel II.
\end{abstract}

KEYWORDS: Banks, Leverage, DSGE models, Basel Accords JEL Classification: E32, E44, E61

${ }^{*}$ Department of Economics, University of Bologna. Mail: matteo.falagiarda2@unibo.it Address: Piazza Scaravilli 2 - 40126 Bologna (Italy). Office Phone: +39 0512092641

${ }^{\dagger}$ Department of Economics, University of Bologna

${ }^{\ddagger}$ We benefited from the encouragement and suggestions of Massimiliano Marzo and Paolo Zagaglia. We thank participants at the 5th Conference of the International Finance and Banking Society. The usual disclaimer applies. 


\section{Introduction}

Until the early 2000s, large-scale structural macro models, such as Dynamic Stochastic General Equilibrium (DSGE) models, have often neglected financial and credit dynamics, with a few notable exceptions (Christiano et al., 2003). Most of the policy models currently employed by central banks (Smets and Wouters, 2003; Christiano et al., 2005; Christoffel et al., 2008) either assume frictionless financial markets or lack a realistic and comprehensive representation of the financial sector.

The recent growing interaction between the real economy and financial markets along with the emergence of several questions linked to financial stability, macro-prudential regulations and monetary policy, has provided a strong motivation to create fully articulated macroeconomic models describing the role of financial frictions and structures in a modern market economy. As the recent global downturn unfolded, the necessity of reforming standard macro models along these lines has become even more urgent.

However, the literature on macroeconomic modeling and that regarding financial and credit market imperfections have run for a long time on parallel paths without converging. ${ }^{1}$ As for the latter, it has long been recognized that financial markets are highly imperfect (Jaffee and Russell, 1976; Stiglitz and Weiss, 1981). Asymmetric information between borrowers and lenders, costly state verification issues, and the eventuality of bankruptcies, defaults and contagions, are the main factors that may potentially disrupt the smooth working of financial and credit markets. It follows that agents are not able to perfectly smooth consumption in reaction to shocks, and business cycle fluctuations are likely to be amplified.

This financial accelerator effect, whereby shocks to the net worth of agents have procyclical effects on their borrowing capacity, amplifying, in such a way, business cycle fluctuations, has been first formalized by Bernanke and Gertler (1989), and subsequently incorporated into structural macroeconomic models by Bernanke et al. $(1996,1999)$ and Kiyotaki and Moore (1997). In the first case, the so-called costly state verification setting,

\footnotetext{
${ }^{1}$ The following literature review is far from being exhaustive. For a comprehensive survey, see Roger and Vlcek (2012).
} 
the financial accelerator effect occurs because the premium on external financing, which depends on the net worth, is procyclical, implying that economic disturbances influence the borrowing capacity of agents. In Kiyotaki and Moore (1997), the amplification of business cycles' magnitude and persistence arises because of the dynamic interactions between borrowing limits and asset prices, generated by explicitly modeling collateral for loans.

Frictions relying on the costly state verification and default risk à la Bernanke et al. (1999) and limited enforceability and collateralized debt à la Kiyotaki and Moore (1997) have been recently employed to enrich standard DSGE models (Aoki et al., 2004; Gertler et al., 2007; Christensen and Dib, 2008; Iacoviello, 2005; Iacoviello and Neri, 2010; Lombardo and McAdam, 2012). ${ }^{2}$

Most of the earlier macroeconomics literature imposed financial frictions on nonfinancial borrowers, treating financial intermediaries as a veil. Modeling financial intermediaries entails the presence of a more or less structured bank's balance sheet, which establishes a link between banking activity and the macroeconomy. Some recent models with financial intermediaries emphasize the demand side of credit, i.e. a perfectly competitive banking sector accommodates any changes in the demand for credit coming from households and firms (Christiano et al., 2003, 2008, 2010).

Another strand of the literature captures supply side aspects of credit dynamics by introducing a more realistic representation of financial intermediaries. First of all, the work by Gerali et al. (2010) paved the way to a flourishing literature that models banks with a certain degree of market power (Dib, 2010; Andrés and Arce, 2012). In Gerali et al. (2010), banks, by operating in monopolistically competitive markets, impose interest rates on loans and deposits that are, respectively, policy rate markups and markdowns. This amplifies the effect of policy rate movements for borrowers, and attenuates those for lenders. Therefore, the transmission mechanisms of shocks are richer in comparison with standard models.

\footnotetext{
${ }^{2}$ Recent extensions to these settings try to introduce endogenous default (Forlati and Lambertini, 2011), and substantial non-linearities to generate "occasionally binding" collateral constraints (Mendoza, 2010).
} 
A second important element is the presence of bank capital and, in particular, capital requirements for banking activity. Bank capital requirements are usually imposed to limit the moral hazard on the part of banks arising with deposit insurance. However, capital requirements are costly because they reduce the possibility for banks to create liquidity. Meh and Moran (2010) introduce bank capital to model moral hazard problems between borrowers and investors. In other contributions (den Heuvel, 2008; Angeloni and Faia, 2013; Zhang, 2009; Dib, 2010; Gerali et al., 2010; Agénor et al., 2012; Angelini et al., 2012), bank capital is motivated by regulatory requirements. In fact, recent events have strengthened the role of the so-called "prudential" policies, namely policies that, focusing on the interactions between financial institutions, markets and the business cycle, aim at mitigating the impact of financial fluctuations. ${ }^{3}$ Usual instruments of macroprudential policies are countercyclical capital and liquidity requirements, and loan-tovalue (LTV) ratios. Modeling bank capital requirements allows economists: a) to analyze the macroeconomic impact of regulations (e.g. how regulatory instruments can attenuate the tendency of the economy to over-leverage during booms and deleverage during busts); ${ }^{4}$ b) to better capture the effect of shocks originating in financial markets; c) to study how the transmission of shocks is altered depending on the strength of the financial sector, and, in particular, how macro-prudential and monetary policies can be coordinated and combined effectively. ${ }^{5}$

Within this research area, Angelini et al. (2012), by adapting the model by Gerali et al. (2010), analyze the strategic interaction between macro-prudential policies and monetary policy. They consider two types of interaction between monetary and regulatory authorities: cooperative and non-cooperative interaction. Their results suggest that when the economy is hit by supply shocks (i.e. in normal times), macro-prudential policies have limited effect on macroeconomic stability. By contrast, when the economy is hit by

\footnotetext{
${ }^{3}$ Prudential policies are, for example, provided for by the Basel Accords. For an extensive and updated review on prudential policies see Beau et al. (2012) and Galati and Moessner (2012).

${ }^{4}$ There is indeed strong empirical evidence that bank leverage is strongly procyclical (Adrian and Shin, 2010b).

${ }^{5}$ As stressed by Beau et al. (2012), the reason for the close link between macro-prudential and monetary policies is that they work through the same transmission channels, such as the bank lending and the balance sheet channels.
} 
financial shocks (i.e. in extraordinary times), macro-prudential policies help to stabilize macroeconomic fluctuations, and cooperation with monetary policy plays an important role in strengthening this effect.

By embracing the supply side approach in modeling the banking sector, this paper proposes a new DSGE model able to analyze the interconnections between financial markets and the macroeconomy. In particular, we adopt some of the elements present at the frontiers of research, highlighted above, and add to them. First of all, in line with some existing contributions in the literature, the model exhibits financially constrained households à la Iacoviello (2005), whose capacity to borrow is tied to the value of their real estate holdings, and a rich banks' balance sheet representation including deposits, loans to households, government bonds, loans from the central bank, and bank's equity. Hence, balance sheet choices are totally endogenous and the model features procyclical leverage.

Second, this leverage procyclicality is strengthened by the presence of proxies for measured risk, which are expressed in a novel formulation. While most of the existing general equilibrium models assume constant LTV ratios, empirical evidence shows that this value varies substantially over time, also reflecting movements in risk perception in financial markets (Gruss and Sgherri, 2009; Campbell and Cocco, 2011). ${ }^{6}$ Partially drawing on Angelini et al. (2012), our setting endogenizes LTV ratios by expressing them as a function of proxies for both systemic and idiosyncratic risk, both at the level of households and banks. ${ }^{7}$ Moreover, we propose a novel formulation of the targeted leverage ratio, in which assets are risk-weighted by cyclical risk-sensitivity measures. ${ }^{8}$ Inspired by the empirical evidence suggesting that procyclical leverage affects aggregate volatility and particularly the price of risk (Adrian and Shin, 2010b), the proxies for risk perception and the risk-sensitivity measures depend, inter alia, on the leverage conditions

\footnotetext{
${ }^{6}$ Furthermore, LTV ratios vary significantly also across countries, reflecting differences in legal and regulatory frameworks (Calza et al., 2007).

${ }^{7}$ Endogenous LTV ratios have also been proposed by Lambertini et al. (2011). In this model, the endogenous LTV is derived based on an agency problem between lenders and borrowers.

${ }^{8} \mathrm{~A}$ similar formulation is proposed by Agénor et al. (2012), who relate instead the risk-measures to the repayment probability.
} 
of households and banks.

The new role for risk combined with endogenous balance sheet choices, allows us, among the other things, to better analyze how financial intermediaries affect the conduct of monetary policy, and, in particular, to isolate the risk-taking channel of monetary policy described by Adrian and Shin (2010a). According to this channel, monetary policy actions affect the risk-taking capacity of banks, leading to shifts in the supply of credit.

Third, banks are subjected to the standard tool used by regulatory authorities, i.e. capital requirements. The innovative formulation of the targeted leverage ratio includes two types of banking assets, namely loans to households and government bonds. As already stressed, the targeted leverage ratio presents an endogenous source of risk perception that differs among asset classes. Since both loans to households and government bonds are considered risky assets, the model is particularly suitable to investigate in a realistic way the effectiveness of different prudential regimes.

A fourth key peculiarity of the model is the presence of a structured connection between financial intermediaries and the monetary authority in order to better capture monetary policy transmission dynamics. We do this by introducing financially constrained banks besides financially constrained households. More specifically, the amount of loans that banks can receive from the central bank is subject to a collateralized borrowing constraint. Loans to households and government bonds are assumed to be employed as collateral by banks. These features aim at reproducing the lending facilities usually offered by monetary authorities to banks.

In light of the novelties introduced, our model represents a unique instrument for simulating, within a general equilibrium framework, credit crunch dynamics and analyzing the effect of prudential regulatory measures. The results highlighted in the paper are important along two dimensions. First, the model provides new insights on the interactions between the banking and credit sectors and the rest of the economy. Second, and more importantly, it contributes to deeper understand the role of supervisory authorities in affecting business cycle fluctuations and in restoring macroeconomic and financial stability. 
More precisely, our findings suggest that the presence of endogenous LTV ratios exacerbates the severity of a simulated credit crunch, and, more generally, the procyclicality of lending conditions, in comparison with a baseline model without these features, and it is thus able to reproduce the salient facts of the recent financial crisis. Endogenous risk weights and LTV ratios are capable of affecting substantially lending quantities, due to the interaction between: a) movements in the LTV ratios, due to changes in labor marketand macroeconomic conditions; b) movements in the weighted leverage cost, due to the combination of changes in interest rates and housing prices, which affect the perception of risk associated with mortgage assets held by banks.

Lastly, by modifying the configuration of the key parameters and steady-states of the model, we are able to compare different prudential policy regimes, such as the Basel Accords. The results suggest that when the economy is mainly affected by standard macroeconomic shocks (normal times), prudential regulatory regimes like Basel II and Basel III increase the volatility of macroeconomic and credit variables. By contrast, when the economy is severely stressed by shocks originating in the financial sector (extraordinary times), these regimes are capable of downsizing substantially aggregate volatility, making business cycle fluctuations smoother, with Basel III found to be significantly more effective than Basel II.

The remainder of the paper is organized as follows. Section 2 elaborates the model and introduces its key features. Section 3 presents the main results. Section 4 concludes.

\section{The Model}

A stylized representation of the model economy is sketched in Figure 1. The economy is populated by two types of households, namely constrained and unconstrained households. Constrained households supply labor inputs and accumulate housing stock, while unconstrained households supply capital inputs. Monopolistically competitive firms hire labor and capital to produce differentiated goods. The two groups of households exhibit a different discount factor, i.e. they discount differently the stream of future utility, which ensures positive financial flows in equilibrium. Thus, constrained households borrow a 
positive amount of loans from banks, whereas unconstrained households invest their resources by purchasing positive amounts of deposits and zero-coupon government bonds. The availability of loans to constrained households is subject to a borrowing constraint linked to the market value of their housing stock. Banks operate in a perfect competitive market. The asset side of their balance sheet is composed of government bonds and loans to households. They are assumed to purchase government bonds. Loans to households and purchases of government bonds are financed by collection of deposits, net worth, and loans from the central bank collateralized against banks' asset holdings. ${ }^{9}$ Lastly, a consolidated government-central bank conducts: a) a standard passive fiscal policy; b) a standard monetary policy consisting in setting the policy rate via a Taylor rule; c) a monetary policy involving the lending facility for banks.

\subsection{Constrained Households}

Preferences of the representative constrained household are defined over consumption $C_{t}^{C}$, real money balances $\frac{M_{t}^{C}}{P_{t}}$, hours worked $F_{t}$, and real stock of housing $\frac{H_{t}}{P_{t}}$, and are described by the infinite stream of utility:

$$
U_{t}^{C}=\sum_{t=0}^{\infty} \beta_{C}^{t} u^{C}\left(C_{t}^{C}, \frac{M_{t}^{C}}{P_{t}}, F_{t}, \frac{H_{t}}{P_{t}}\right)
$$

where $\beta_{C}$ is the intertemporal discount factor.

The instantaneous utility function of the representative constrained household $u^{C}\left(C_{t}^{C}, \frac{M_{t}^{C}}{P_{t}}, F_{t}, \frac{H_{t}}{P_{t}}\right)$ is given by:

$u^{C}\left(C_{t}^{C}, \frac{M_{t}^{C}}{P_{t}}, F_{t}, \frac{H_{t}}{P_{t}}\right)=\frac{\left(C_{t}^{C}-\gamma C_{t-1}^{C}\right)^{1-\frac{1}{\sigma}}}{1-\frac{1}{\sigma}}+\frac{1}{1-\chi}\left(\frac{M_{t}^{C}}{P_{t}}\right)^{1-\chi}-\frac{\Psi}{1+1 / \psi} F_{t}^{1+1 / \psi}+J^{h} \log \frac{H_{t}}{P_{t}}$

where $\gamma$ measures the importance of consumption habits, $\sigma$ is the elasticity of intertemporal substitution, $\chi$ is the elasticity of money demand, and $\psi$ is the Frisch elasticity of

\footnotetext{
${ }^{9}$ This is a sort of discount window offered by the monetary authority to banks.
} 
labor supply.

In this economy, each agent (both constrained and unconstrained) can choose the composition of a basket of differentiated final goods. Preferences across varieties of goods have the standard constant elasticity of substitution (CES) form à la Dixit and Stiglitz (1977):

$$
C_{t}=\left[\int_{0}^{1} C_{t}(j)^{\frac{\theta_{t}-1}{\theta_{t}}} d j\right]^{\frac{\theta_{t}}{\theta_{t}-1}}
$$

where $C_{t}$ is the aggregate consumption index of all the differentiated final goods produced in the economy under monopolistic competition. There are $j$-th varieties of final goods $(j \in[0,1])$, and $\theta$ is the elasticity of substitution between different final goods varieties $(\theta>1)$.

Each constrained agent is subject to the following budget constraint:

$$
C_{t}^{C}+\frac{P_{t}^{H} H_{t}}{P_{t}}+\frac{L_{t-1}^{C} R_{t-1}^{C}}{P_{t}}+\frac{M_{t}^{C}}{P_{t}}+T_{t}^{C}=\frac{M_{t-1}^{C}}{P_{t}}+\frac{L_{t}^{C}}{P_{t}}+w_{t} F_{t}+\frac{P_{t-1}^{H} H_{t-1}}{P_{t}}
$$

Constrained agents allocate their wealth among money holding $M_{t}^{C}$ and housing $H_{t}$, where $P_{t}^{H}$ is the price of houses. They receive wage income $w_{t} F_{t}$, where $w_{t}$ is the real wage (hereafter, lower-case letters denote real variables). They also pay a real lump-sum $\operatorname{tax} T_{t}^{C}$. Constrained households borrow from banks an amount of loans $L_{t}^{C}$ at the interest rate $R_{t}^{C}$. $P_{t}$ is the aggregate price level. The housing stock is assumed to be fixed. A shock to the house price level, $\nu_{t}^{H}$, is introduced. It follows an $\operatorname{AR}(1)$ process with an i.i.d. disturbance $\varepsilon_{t}^{P^{H}}$ with zero mean and standard deviation $\sigma_{P^{H}}$.

Moreover, each constrained household is also subject to the following borrowing constraint:

$$
\frac{L_{t}^{C} R_{t}^{C}}{P_{t}} \leq L T V_{t}^{C} E_{t}\left[\frac{P_{t+1}^{H} H_{t}}{P_{t+1}}\right]
$$

Thus, constrained households can borrow from banks, but the expected value of their housing stock must guarantee repayment of loans and interests, as in Iacoviello (2005) and 
Iacoviello and Neri (2010). $L T V_{t}^{C}$ is the loan-to-value ratio of the constrained agent and reflects the preferences of banks. As stressed by Gerali et al. (2010), from a microeconomic point of view it can be interpreted as the cost of collateral repossession for banks in case of default. Differently from most of previous studies, which assume an exogenous LTV ratio, $L T V_{t}^{C}$ is determined endogenously by the following equation:

$$
\frac{L T V_{t}^{C}}{L T V^{C}}=\left(\frac{L T V_{t-1}^{C}}{L T V^{C}}\right)^{\phi_{L T V^{C}}}\left(\frac{P_{t}^{H} H_{t}}{P^{H} H}\right)^{\varphi_{1, H}}\left(\frac{w_{t} F_{t}}{w F}\right)^{\varphi_{2, H}}\left(\frac{Y_{t}}{Y}\right)^{\varphi_{3, H}} \exp \left(\varepsilon_{t}^{L T V^{C}}\right)
$$

where variables without the temporal subscript denote steady-state values. $\phi_{L T V^{C}}$ is an autoregressive parameter, $0<\phi_{L T V^{C}}<1$, to model sluggish LTV changes over time. $\varepsilon_{t}^{L T V^{C}}$ is an i.i.d. shock with zero mean and standard deviation $\sigma_{L T V^{C}}$. In the right-hand side of (6) we can distinguish other three terms. The first term represents the variation in the value of the stock of houses held by constrained households relative to its steadystate value, and it is a proxy for the value of the collateral. The second term measures variations in the labor income of constrained households relative to its steady-state value to capture the risk related to households' income fluctuations. We then add a component associated with fluctuations of output around its steady-state level: it is a proxy for the systemic risk of the economy. It is assumed that $\varphi_{1, H}, \varphi_{2, H}, \varphi_{3, H} \geq 0$, i.e. increases in the value of the stock of houses, real labor income, and aggregate income, lead to an increase in the LTV ratio, allowing constrained households to expand their borrowing capacity. Thanks to this formulation, we are able to endogenize the amount of credit that banks provide to constrained households given the value of their collateral.

Constrained households maximize their lifetime utility (1), subject to the budget constraint (4) and the borrowing constraint (5). The first order necessary conditions with respect to consumption, labor, money, houses, and loans are respectively given by:

$$
\left(C_{t}^{C}-\gamma C_{t-1}^{C}\right)^{-1 / \sigma}-\beta_{C} \gamma E_{t}\left[\left(C_{t+1}^{C}-\gamma C_{t}^{C}\right)^{-1 / \sigma}\right]=\lambda_{t}^{C}
$$




$$
\begin{aligned}
& \Psi F_{t}^{1 / \psi}=\lambda_{t}^{C} w_{t}-E_{t}\left[\frac{\mu_{t}^{C} \varphi_{2, H} L T V_{t}^{C} P_{t+1}^{H}}{\pi_{t+1}}\right] \\
& \left(m_{t}^{C}\right)^{-\chi}+\beta_{C} E_{t}\left[\frac{\lambda_{t+1}^{C}}{\pi_{t+1}}\right]=\lambda_{t}^{C} \\
& \frac{J^{h}}{h_{t}}=\lambda_{t}^{C} P_{t}^{H}-E_{t}\left[\frac{\beta_{C} \lambda_{t+1}^{C} P_{t}^{H}}{\pi_{t+1}}\right]-E_{t}\left[\frac{\mu_{t}^{C} L T V_{t}^{C} P_{t+1}^{H}}{\pi_{t+1}}\right]-E_{t}\left[\frac{\mu_{t}^{C} \varphi_{1, H} L T V_{t}^{C} P_{t+1}^{H}}{\pi_{t+1}}\right] \\
& \lambda_{t}^{C}=\beta_{C} E_{t}\left[\frac{\lambda_{t+1}^{C} R_{t}^{C}}{\pi_{t+1}}\right]+\mu_{t}^{C} R_{t}^{C}
\end{aligned}
$$

where $\lambda_{t}^{C}$ and $\mu_{t}^{C}$ are the Lagrange multipliers, and $\pi_{t}$ is the gross inflation rate $\left(\pi_{t}=\right.$ $\left.P_{t} / P_{t-1}\right)$.

\subsection{Unconstrained Households}

The preferences of the representative unconstrained households are defined over consumption $C_{t}^{U}$ and an aggregator of real monetary assets $x_{t}$, and are described by the infinite stream of utility:

$$
U_{t}^{U}=\sum_{t=0}^{\infty} \beta_{U}^{t} u^{U}\left(C_{t}^{U}, x_{t}\right)
$$

where $\beta_{U}$ is the intertemporal discount factor. In line with the existing literature, we assume that $\beta_{U}<\beta_{C}$, so that agents with a lower discount factor are savers in equilibrium, whereas agents with a higher discount factor are borrowers in equilibrium.

The instantaneous utility function of the representative unconstrained household $u^{U}\left(C_{t}^{U}, x_{t}\right)$ 
is given by:

$$
u^{U}\left(C_{t}^{U}, x_{t}\right)=\frac{\left(C_{t}^{U}-\gamma C_{t-1}^{U}\right)^{1-\frac{1}{\sigma}}}{1-\frac{1}{\sigma}}+\eta_{x} \log x_{t}
$$

where $\eta_{x}>0$. Drawing on Agénor et al. (2012), the composite index of real monetary assets $x_{t}$ is defined via a Cobb-Douglas function:

$$
x_{t}=\left(m_{t}^{U}\right)^{v} d_{t}^{1-v}
$$

where $m_{t}^{U}$ indicates real money balances, $d_{t}$ real deposits. $v$ measures the importance of real money balances in the liquidity bundle $(0<v<1) .{ }^{10}$

Each unconstrained agent is subject to the following budget constraint:

$$
\frac{B_{t}^{U}}{P_{t} R_{t}^{B}}+\frac{M_{t}^{U}}{P_{t}}+C_{t}^{U}+T_{t}^{U}+\frac{D_{t}}{P_{t}}+I_{t}\left(1+A C_{t}^{I}\right)=\frac{B_{t-1}^{U}}{P_{t}}+\frac{M_{t-1}^{U}}{P_{t}}+\frac{D_{t-1} R_{t-1}^{D}}{P_{t}}+q_{t} K_{t}+\left(1-\phi^{B}\right) \Omega_{t}^{B}
$$

Thus, unconstrained agents allocate their wealth among money holding $M_{t}^{U}$, deposits $D_{t}$, which pay an interest $R_{t}^{D}$, and holding of zero-coupon government bonds $B_{t}^{U}$. They receive rental income $q_{t} K_{t}$ (where $K_{t}$ is capital and $q_{t}$ the rental rate), and a fraction $\left(1-\phi^{B}\right)$ of banks' profits $\Omega_{t}^{B}$. They also pay a real lump-sum tax $T_{t}^{U}$. $I_{t}$ is investment.

Unconstrained households accumulate capital and rent it to firms. The law of motion of capital stock is expressed in the following standard way:

$$
K_{t}=I_{t-1}+(1-\delta) K_{t-1}
$$

where $\delta$ represents the depreciation rate of the capital stock. In addition, unconstrained

\footnotetext{
${ }^{10}$ This formulation originates from a recent approach of modeling transaction services via CES bundles of different assets. See, for example, Canzoneri et al. (2008, 2011).
} 
households face quadratic adjustment costs of investment as in Kim (2000):

$$
A C_{t}^{I}=\frac{\phi_{K}}{2}\left(\frac{I_{t}}{K_{t}}\right)^{2}
$$

where $\phi_{K}$ is the adjustment cost scale parameter for capital.

Unconstrained households maximize their lifetime utility (12), subject to the budget constraint (15) and the capital accumulation equation (16). The first order necessary conditions with respect to consumption, money, deposits, bonds, capital and investment are respectively given by:

$$
\begin{aligned}
& \left(C_{t}^{U}-\gamma C_{t-1}^{U}\right)^{-1 / \sigma}-\beta_{U} \gamma E_{t}\left[\left(C_{t+1}^{U}-\gamma C_{t}^{U}\right)^{-1 / \sigma}\right]=\lambda_{t}^{U} \\
& \frac{\eta_{x} v}{m_{t}^{U}}+\beta_{U} E_{t}\left[\frac{\lambda_{t+1}^{U}}{\pi_{t+1}}\right]=\lambda_{t}^{U} \\
& \frac{\eta_{x}(1-v)}{d_{t}}+\beta_{U} E_{t}\left[\frac{\lambda_{t+1}^{U} R_{t}^{D}}{\pi_{t+1}}\right]=\lambda_{t}^{U} \\
& \beta_{U} E_{t}\left[\frac{\lambda_{t+1}^{U}}{\pi_{t+1}}\right]=\frac{\lambda_{t}^{U}}{R_{t}^{B}} \\
& \beta_{U} E_{t}\left[\mu_{t+1}^{U}\right]=\lambda_{t}^{U}\left(1+\frac{3}{2} \phi_{K}\left(\frac{I_{t}}{K_{t}}\right)^{2}\right) \\
& \beta_{U}(1-\delta) E_{t}\left[\mu_{t+1}^{U}\right]=\mu_{t}^{U}-\lambda_{t}^{U}\left(q_{t}+\phi_{K}\left(\frac{I_{t}}{K_{t}}\right)^{3}\right)
\end{aligned}
$$


where $\lambda_{t}^{U}$ and $\mu_{t}^{U}$ are the Lagrange multipliers.

\section{$2.3 \quad$ Firms}

The firms' sector is modeled in a standard way. Each $j$-th firm produces and sells differentiated final goods in a monopolistically competitive market. The production function is a standard Cobb-Douglas with labor provided by constrained households and capital by unconstrained households (i.e. the owners of firms):

$$
Y_{t}=A_{t} K_{t}^{\alpha} F_{t}^{1-\alpha}-\Phi
$$

where $\alpha$ is the share of capital used in production, and $\Phi$ is a fixed cost to ensure that profits are zero in the steady-state. $A_{t}$ is technology and follows an $\mathrm{AR}(1)$ process:

$$
\log \left(\frac{A_{t}}{A}\right)=\phi_{A} \log \left(\frac{A_{t-1}}{A}\right)+\varepsilon_{t}^{A}
$$

where $\varepsilon_{t}^{A}$ is an i.i.d. shock with zero mean and standard deviation $\sigma_{A}$.

Firms' optimizing process is constrained by nominal rigidities à la Rotemberg (1982), i.e. firms face quadratic price adjustment costs:

$$
A C_{t}^{P}=\frac{\phi_{P}}{2}\left(\frac{P_{t}(j)}{P_{t-1}(j)}-\pi\right)^{2} Y_{t}
$$

Given the standard CES setting of equation (3), the demand function faced by each single firm $j$ is:

$$
Y_{t}(j)=\left[\frac{p_{t}(j)}{P_{t}}\right]^{-\theta_{t}} Y_{t} \Longrightarrow P_{t}(j)=\left[\frac{Y_{t}(j)}{Y_{t}}\right]^{-\frac{1}{\theta_{t}}} P_{t}
$$

Thus, the demand function for each single good $j$ is proportionally related to the output level of the economy, and negatively to the price of good $j$. 
Following Kim (2000), the profit function for each firm $j$ is:

$$
P_{t} \Pi_{t}(j)=P_{t}(j) Y_{t}(j)-P_{t} w_{t} F_{t}(j)-P_{t} q_{t} K_{t}(j)-P_{t} A C_{t}^{P}
$$

After employing (26) and (27) into (28), the maximization problem of each firm becomes fully dynamic: each firm maximizes the expectation of the discounted sum of profit flows, given the information at time 0 :

$$
\Pi_{0}(j)=E_{0}\left[\sum_{t=0}^{\infty} \rho_{t} P_{t} \Pi_{t}(j)\right]
$$

where $\rho$ is the discount factor of firms.

By assuming that each agent in the economy has access to a complete market for contingent claims, the discount factors of unconstrained households and firms are equal:

$$
E_{t}\left[\frac{\rho_{t+1}}{\rho_{t}}\right]=\beta^{U} E_{t}\left[\frac{\lambda_{t+1}^{U}}{\lambda_{t}^{U}}\right]
$$

Therefore, the necessary first order conditions of the maximization problem with respect to labor and capital are given respectively by:

$$
\begin{aligned}
& w_{t}=(1-\alpha)\left(\frac{Y_{t}+\Phi}{F_{t}}\right)\left(1-\frac{1}{e_{t}^{Y}}\right) \\
& q_{t}=\alpha\left(\frac{Y_{t}+\Phi}{K_{t}}\right)\left(1-\frac{1}{e_{t}^{Y}}\right)
\end{aligned}
$$

where $e_{t}^{Y}$ is the output demand elasticity:

$$
\frac{1}{e_{t}^{Y}}=\frac{1}{\theta}\left\{1-\phi_{P}\left(\pi_{t}-\pi\right) \pi_{t}+\beta^{U} \phi_{P} E_{t}\left[\frac{\lambda_{t+1}^{U}}{\lambda_{t}^{U}}\left(\pi_{t+1}-\pi\right) \pi_{t+1}^{2} \frac{Y_{t+1}}{Y_{t}}\right]\right\}
$$

which measures the gross price markup over marginal cost. It is easy to check that manipulations of the log-linearized version of (33) lead to the standard New Keynesian 
Phillips curve.

\subsection{Banks}

The banking sector is characterized by a continuum of banks facing perfect competition. ${ }^{11}$ Banks borrow from the central bank $L_{t}^{C B}$ at the rate $R_{t}^{C B}$ (i.e. the policy rate) and receive deposits $D_{t}$ from unconstrained households (liability side of the balance sheet), invest in government bonds $B_{t}^{B}$ and provide loans to constrained households $L_{t}^{C}$ (asset side of the balance sheet). Thus, the balance sheet identity of the representative bank is given by:

$$
B_{t}^{B}+L_{t}^{C}=Z_{t}+D_{t}+L_{t}^{C B}
$$

where $Z_{t}$ represents the equity (net worth, capital) of the bank.

Each bank maximizes the present discounted value of its profits:

$$
\begin{aligned}
& E_{0} \sum_{t=0}^{\infty} \beta_{B}\left[\frac{R_{t}^{C} L_{t}^{C}}{P_{t}}-\frac{L_{t+1}^{C}}{P_{t}}+\frac{R_{t}^{B} B_{t}^{B}}{P_{t}}-\frac{B_{t+1}^{B}}{P_{t}}-\frac{R_{t}^{D} D_{t}}{P_{t}}+\frac{D_{t+1}}{P_{t}}-\frac{Z_{t}}{P_{t}}+\frac{Z_{t+1}}{P_{t}}-\right. \\
& \left.-\frac{R_{t}^{C B} L_{t}^{C B}}{P_{t}}+\frac{L_{t+1}^{C B}}{P_{t}}-\frac{e}{2}\left(\frac{w_{t}^{C} L_{t}^{C}+w_{t}^{G} B_{t}^{B}}{Z_{t}}-\nu^{b}\right)^{2} \frac{Z_{t}}{P_{t}}-\frac{\gamma^{C}}{2}\left(\frac{L_{t}^{C}}{P_{t}}\right)^{2}\right]
\end{aligned}
$$

where $\beta_{B}$ is the discount factor of banks. The second to last term in (35) represents a quadratic cost that banks pay in terms of their equity whenever they move away from a leverage ratio $\nu^{b}$ (i.e. assets over equity) imposed by regulators. The presence of these costs is justified by the recent experience of many advanced economies, where authorities have proposed to introduce a leverage ratio as a regulatory tool. By modifying the imposed leverage ratio, it is possible to assess the impact of a stricter or looser macroprudential policy. ${ }^{12}$ The presence of capital requirements combined with a balance sheet identity like (34) has important implications for the dynamics of the model. In fact, any economic disturbance that affects banks' balance sheet composition forces financial

\footnotetext{
${ }^{11}$ An extension with monopolistic competition à la Gerali et al. (2010) is left for future research.

${ }^{12}$ For simplicity, we do not distinguish between required capital and countercyclical capital buffers held voluntarily by banks. For a discussion, see Angelini et al. (2010). Moreover, we do not introduce a countercyclical capital requirements rule as in Angelini et al. (2011).
} 
intermediaries to modify their leverage, leading to shifts in the supply of credit. As highlighted by Adrian and Shin (2010a), this transmission channel played a crucial role in the recent crisis. The last term in equation (35) captures an additional cost of managing loans to households.

Drawing on Roger and Vlček (2011), the leverage ratio incorporates two different risk weights for loans to households $\left(w_{t}^{C}\right)$ and government bonds $\left(w_{t}^{G}\right)$. These variables can be considered proxies for the perception of the risk embedded in the asset side of the balance sheet of banks. The time-varying risk weights aim at capturing the nature of risk-sensitive regulatory frameworks such as Basel II and Basel III. We propose the following novel formulation for the two risk weights:

$$
\begin{aligned}
& \frac{w_{t}^{G}}{w^{G}}=\left(\frac{w_{t-1}^{G}}{w^{C}}\right)^{\phi_{w^{G}}}\left(\frac{B_{t}}{Y_{t}} \kappa_{B}\right)^{\varphi_{1, w} G}\left(\frac{Y_{t}}{Y}\right)^{\varphi_{2, w^{G}}} \exp \left(\varepsilon_{t}^{w^{G}}\right) \\
& \frac{w_{t}^{C}}{w^{C}}=\left(\frac{w_{t-1}^{C}}{w^{C}}\right)^{\phi_{w} C}\left(\frac{L_{t}^{C} R_{t}^{C}}{P_{t}^{H} H_{t}} \kappa_{L}\right)^{\varphi_{1, w^{C}}}\left(\frac{L_{t}^{C}}{Z_{t}} \kappa_{Z}\right)^{\varphi_{2, w^{C}}}\left(\frac{Y_{t}}{Y}\right)^{\varphi_{3, w} C} \exp \left(\varepsilon_{t}^{w^{C}}\right)
\end{aligned}
$$

where $\varphi_{1, w^{G}}, \varphi_{1, w^{C}}, \varphi_{2, w^{C}} \geq 0, \varphi_{2, w^{G}}, \varphi_{3, w^{C}} \leq 0$, and $\kappa_{B}=\frac{Y}{B}, \kappa_{L}=\frac{P^{H} H}{L^{C} R^{C}}$, and $\kappa_{Z}=\frac{Z}{L^{C}}$. $\phi_{w^{G}}$ and $\phi_{w^{C}}$ are autoregressive parameter $\left(0<\left(\phi_{w^{G}}, \phi_{w^{C}}\right)<1\right)$. $\varepsilon_{t}^{w^{G}}$ and $\varepsilon_{t}^{w^{C}}$ are i.i.d. shocks with zero mean and standard deviation $\sigma_{w^{G}}$ and $\sigma_{w^{C}}$, respectively.

The intuition behind (36) and (37) is as follows. Equation (36) models the risk associated with government debt. This risk is assumed to increase with government's total debt exposure $\left(B_{t} / Y_{t}\right)$. The first term in the right-hand side of (37) represents a proxy for the leverage position of constrained households, expressed as the ratio between the value of loans and the value of household's collateral: the higher is this ratio, the higher is the perceived risk associated with $L_{t}^{C}$. The second term indicates the risk embedded in the balance sheet of banks: the perceived risk is an increasing function of the ratio between the amount of loans provided to households and the equity of banks. Thus, the sign of $\varphi_{1, w^{C}}$ and $\varphi_{2, w^{C}}$ in our calibration suggests that the risk increases as the leverage of households and the exposure of banks increase. Lastly, both equations feature 
a component related to the macroeconomic situation capturing systemic risk. Notice that if $w_{t}^{G}$ and $w_{t}^{C}$ are assumed to be fixed and equal to 1 (as in the steady-state situation), the leverage cost in equation (35) boils down to the more standard formulation usually adopted in the literature.

Equation (35) highlights another source of financing for banks (besides deposits from unconstrained households), namely loans from the central bank. Since this reflects standard lending facilities usually provided for by monetary authorities, banks are required to offer collateral. Therefore, similarly to what seen for constrained households, each bank is subject to a borrowing constraint:

$$
\frac{R_{t}^{C B} L_{t}^{C B}}{P_{t}} \leq \phi_{B}^{C B} L T V_{B, t}^{C B} E_{t}\left[\frac{B_{t}^{B}}{R_{t+1}^{B} P_{t+1}}\right]+\phi_{C}^{C B} L T V_{C, t}^{C B} E_{t}\left[\frac{L_{t}^{C}}{R_{t+1}^{C} P_{t+1}}\right]
$$

Thus, equation (38) introduces a collateralized lending market between banks and the central bank. Both government bonds (the first term on the right-hand side) and mortgagebacked securities (the second term on the right-hand side) can be considered as general collateral. The parameters $\phi_{B}^{C B}$ and $\phi_{C}^{C B}$ indicate the importance of each component $\left(\phi_{B}^{C B}+\phi_{C}^{C B}=1\right)$. Notice that usual standard lending facilities do not allow banks to use asset-backed securities as eligible collateral. Therefore, in the baseline calibration, the parameter $\phi_{C}^{C B}$ has been set to a low level (0.1). By varying $\phi_{C}^{C B}$ it is possible to simulate some recent measures implemented by central banks that extend the range of possible collaterals. $^{13}$

$L T V_{B, t}^{C B}$ and $L T V_{C, t}^{C B}$ resemble the haircuts applied to the collateral pledged against the credit provided by the central bank to private banks. Although central banks' haircuts are officially fixed, we assume them to be time-varying, since they reflect the underlying risk associated with the collateral. For instance, a downgrading of the eligible collaterals may result in a lower haircut category. Thus, also in this case, the LTV ratios determining the liquidity of the system are endogenized. More specifically, $L T V_{B, t}^{C B}$ and $L T V_{C, t}^{C B}$ are

\footnotetext{
${ }^{13}$ This analysis is not conducted in the present paper.
} 
expressed in the following way:

$$
\frac{L T V_{B, t}^{C B}}{L T V_{B}^{C B}}=\left(\frac{L T V_{B, t-1}^{C B}}{L T V_{B}^{C B}}\right)^{\phi_{L T V_{B}^{C B}}}\left(\frac{B_{t}}{Y_{t}} \kappa_{B}\right)^{\varphi_{1, B}}\left(\frac{Y_{t}}{Y}\right)^{\varphi_{2, B}} \exp \left(\varepsilon_{t}^{L T V_{B}^{C B}}\right)
$$

and

$$
\frac{L T V_{C, t}^{C B}}{L T V_{C}^{C B}}=\left(\frac{L T V_{C, t-1}^{C B}}{L T V_{C}^{C B}}\right)^{\phi_{L T V_{C}^{C B}}}\left(\frac{L_{t}^{C} R_{t}^{C}}{P_{t}^{H} H_{t}} \kappa_{L}\right)^{\varphi_{1, C}}\left(\frac{L_{t}^{C}}{D_{t}} \kappa_{D}\right)^{\varphi_{2, C}}\left(\frac{Y_{t}}{Y}\right)^{\varphi_{3, C}} \exp \left(\varepsilon_{t}^{L T V_{C}^{C B}}\right)
$$

where $\kappa_{D}=\frac{D}{L^{C}}$, and $\phi_{L T V_{B}^{C B}}$ and $\phi_{L T V_{C}^{C B}}$ are autoregressive parameters, $0<\left(\phi_{L T V_{B}^{C B}}, \phi_{L T V_{C}^{C B}}\right)<$ 1. In (39) and (40) we have that $\varphi_{1, B}, \varphi_{1, C}, \varphi_{2, C}<0$ and $\varphi_{2, B}, \varphi_{3, C}>0 . \varepsilon_{t}^{L T V_{B}^{C B}}$ and $\varepsilon_{t}^{L T V_{C}^{C B}}$ are i.i.d. shocks with zero mean and standard deviation $\sigma_{L T V_{B}^{C B}}$ and $\sigma_{L T V_{C}^{C B}}$, respectively. The same reasoning behind equations (36) and (37) applies here too. Therefore, we assume that the LTV ratio associated with government bonds is a function of the proxies for the systemic risk of the economy, while the LTV ratio relative to loans to households is a function of proxies for both idiosyncratic risk of households and banks, and the systemic risk of the economy.

As in Gerali et al. (2010), the law of motion of equity stock is given by:

$$
Z_{t}=\left(1-\delta^{b}\right) Z_{t-1}+\phi^{B} \Omega_{t-1}^{B}
$$

where $\delta^{b}$ represents the cost of managing bank capital (it is analogous to the depreciation rate of physical capital), and $\left(1-\phi^{B}\right)$ summarizes the dividend policy of the bank, which is assumed to be exogenous. Financial intermediaries can accumulate net worth only through retained earnings.

By substituting the definition of $Z_{t+1}$ obtained from (34) forwarded one period into (35), the latter boils down to a one-period profits equation, and the maximization problem 
becomes static. Expected real profits at the end of period $t$ are thus defined as:

$$
E_{t}\left[\frac{\Omega_{t+1}^{B}}{P_{t}}\right]=\frac{R_{t}^{C} L_{t}^{C}}{P_{t}}+\frac{R_{t}^{B} B_{t}^{B}}{P_{t}}-\frac{R_{t}^{D} D_{t}}{P_{t}}-\frac{Z_{t}}{P_{t}}-\frac{R_{t}^{C B} L_{t}^{C B}}{P_{t}}-\frac{e}{2}\left(\frac{w_{t}^{C} L_{t}^{C}+w_{t}^{G} B_{t}^{B}}{Z_{t}}-\nu^{b}\right)^{2} \frac{Z_{t}}{P_{t}}-\frac{\gamma^{C}}{2}\left(\frac{L_{t}^{C}}{P_{t}}\right)^{2}
$$

Banks maximize their profits (42) subject to the balance sheet identity (34) and to the borrowing constraint (38). In order to simplify the maximization problem, we proceed as follows. We isolate $B_{t}^{B}$ from equation (34) and substitute for it wherever it appears in the Lagrangian. Since banks behave competitively, they take the path of all the interest rates as given. Thus, the choice variables for banks are the quantities of deposits, loans to households, equity, and loans from the central bank. The first order necessary conditions with respect to deposits, loans to households, equity, and loans from the central bank are the following:

$$
R_{t}^{D}=R_{t}^{B}+\frac{\mu_{t}^{B} \phi_{B}^{C B} L T V C_{B, t}^{C B}}{E_{t}\left[R_{t+1}^{B} \pi_{t+1}\right]}-\frac{\varphi_{2, C} L_{t}^{C}}{D_{t}} \frac{\mu_{t}^{B} \phi_{C}^{C B} L T V C_{C, t}^{C B}}{E_{t}\left[R_{t+1}^{C} \pi_{t+1}\right]}-w_{t}^{G} e\left(\frac{w_{t}^{C} L_{t}^{C}+w_{t}^{G} B_{t}^{B}}{Z_{t}}-\nu^{b}\right)
$$

$$
\begin{aligned}
& R_{t}^{C}=R_{t}^{B}+\frac{\mu_{t}^{B} \phi_{B}^{C B} L T V C_{B, t}^{C B}}{E_{t}\left[R_{t+1}^{B} \pi_{t+1}\right]}-\left(\varphi_{1, C}+\varphi_{2, C}+1\right) \frac{\mu_{t}^{B} \phi_{C}^{C B} L T V C_{C, t}^{C B}}{E_{t}\left[R_{t+1}^{C} \pi_{t+1}\right]}+ \\
& +e\left[w_{t}^{C}\left(1+\varphi_{1, w^{C}}+\varphi_{2, w^{C}}\right)-w_{t}^{G}\right]\left(\frac{w_{t}^{C} L_{t}^{C}+w_{t}^{G} B_{t}^{B}}{Z_{t}}-\nu^{b}\right)+\gamma^{C} L_{t}^{C} \\
& R_{t}^{B}=1-\frac{\mu_{t}^{B} \phi_{B}^{C B} L T V C_{B, t}^{C B}}{E_{t}\left[R_{t+1}^{B} \pi_{t+1}\right]}+\frac{e}{2}\left(\frac{w_{t}^{C} L_{t}^{C}+w_{t}^{G} B_{t}^{B}}{Z_{t}}-\nu^{b}\right)^{2}+ \\
& +e Z_{t}\left(\frac{w_{t}^{G}-\frac{\varphi_{2, w} L_{t}^{C} w_{t}^{C}}{Z_{t}}}{Z_{t}}-\frac{w_{t}^{C} L_{t}^{C}+w_{t}^{G} B_{t}^{B}}{Z_{t}^{2}}\right)\left(\frac{w_{t}^{C} L_{t}^{C}+w_{t}^{G} B_{t}^{B}}{Z_{t}}-\nu^{b}\right)
\end{aligned}
$$




$$
R_{t}^{B}=R_{t}^{C B}+\mu_{t}^{B} R_{t}^{C B}-\frac{\mu_{t}^{B} \phi_{B}^{C B} L T V C_{B, t}^{C B}}{E_{t}\left[R_{t+1}^{B} \pi_{t+1}\right]}+w_{t}^{G} e\left(\frac{w_{t}^{C} L_{t}^{C}+w_{t}^{G} B_{t}^{B}}{Z_{t}}-\nu^{b}\right)
$$

where $\mu_{t}^{B}$ is the Lagrange multiplier.

\subsection{The Government Sector}

The consolidated government-central bank budget constraint is given by:

$$
\frac{B_{t}}{P_{t} R_{t}^{B}}+\frac{M_{t}}{P_{t}}+\frac{L_{t}^{C B}}{P_{t}}+T_{t}=\frac{B_{t-1}}{P_{t}}+\frac{M_{t-1}}{P_{t}}+\frac{L_{t-1}^{C B} R_{t-1}^{C B}}{P_{t}}+G_{t}
$$

where $B_{t}$ is the stock of government interest-bearing debt held by the public $\left(B_{t}=\right.$ $\left.B_{t}^{B}+B_{t}^{U}\right)$, and $M_{t}$ is the total amount of money held by the public $\left(M_{t}=M_{t}^{C}+M_{t}^{U}\right)$. Government spending, net of interest expenses, $G_{t}$ follows an $\operatorname{AR}(1)$ process:

$$
\log \left(\frac{G_{t}}{G}\right)=\phi_{G} \log \left(\frac{G_{t-1}}{G}\right)+\varepsilon_{t}^{G}
$$

where $\varepsilon_{t}^{G}$ is an i.i.d. shock with zero mean and standard deviation $\sigma_{G}$.

We introduce a passive fiscal policy rule, whereby the total amount of tax collection is a function of total government's liabilities, in order to prevent the emergence of inflation as a fiscal phenomenon, as suggested by Leeper (1991):

$$
T_{t}=\psi_{0}+\psi_{1}\left[\frac{b_{t-1}}{\pi_{t}}-\frac{b}{\pi}\right]
$$

where $\psi_{0}$ is the steady-state level of $T_{t}$. Equation (49) indicates that the level of taxes reacts to deviations of the outstanding level of public debt from its steady-state level. In other words, taxes are not allowed to act independently from the stock of government liabilities outstanding in the economy.

Besides providing loans to banks, the monetary authority sets the policy rate, which is assumed to be the rate on central bank's loans to private banks $R_{t}^{C B}$, according to the 
following Taylor (1993) rule:

$$
\log \left(\frac{R_{t}^{C B}}{R^{C B}}\right)=\alpha_{R} \log \left(\frac{R_{t-1}^{C B}}{R^{C B}}\right)+\left(1-\alpha_{R}\right)\left\{\alpha_{\pi} \log \left(\frac{\pi_{t}}{\pi}\right)+\alpha_{Y} \log \left(\frac{Y_{t}}{Y}\right)\right\}+\varepsilon_{t}^{R}
$$

where $\alpha_{R}, \alpha_{\pi}, \alpha_{Y}$ indicate the response of $R_{t}^{C B}$ to the lagged policy rate, inflation and output, respectively. Thus, the policy rate is determined by the deviation of inflation and output from the steady-state with an interest rate smoothing component. The monetary policy shock $\varepsilon_{t}^{R}$ is an i.i.d. with zero mean and standard deviation $\sigma_{R}$.

\subsection{The Resource Constraint and Aggregation}

The model is completed by specifying the aggregated variables for consumption, money, bonds and taxes:

$$
\begin{aligned}
& C_{t}=C_{t}^{C}+C_{t}^{U} \\
& M_{t}=M_{t}^{C}+M_{t}^{U} \\
& B_{t}=B_{t}^{U}+B_{t}^{B} \\
& T_{t}=T_{t}^{C}+T_{t}^{U}
\end{aligned}
$$

and the resource constraint of the economy:

$$
Y_{t}=C_{t}+G_{t}+I_{t}\left(1+A C_{t}^{I}\right)+A C_{t}^{P}+\frac{e}{2}\left(\frac{w_{t}^{C} L_{t}^{C}+w_{t}^{G} B_{t}^{B}}{Z_{t}}-\nu^{b}\right)^{2} Z_{t}+\frac{\gamma^{C}}{2}\left(L_{t}^{C}\right)^{2}
$$


Total output is allocated to consumption, government spending, investment (comprehensive of capital adjustment costs), price adjustment costs, and a component related to banking sector's frictions.

The model is composed of 43 equations for 43 variables. Since the equilibrium of the model cannot be solved analytically, we log-linearized it around the steady-state. We solved the model using both the MATLAB routine Gensys written by Christopher Sims and Dynare developed by Adjemian et al. (2011). ${ }^{14}$ In what follows, calibration issues are first discussed. We then analyze the properties of the model, highlighting the main results.

\subsection{The Calibration}

The benchmark model is calibrated to match euro area quarterly data over the decade prior to the crisis of 2008. Table 1 and Table 2 report, respectively, some steady-state values and the chosen calibration values for the standard parameters. Some of the steadystates are obtained from the data, or following previous studies. Output is normalized to 1. In the steady-state, 10 percent of consumption is attributed to constrained households, while 90 percent to unconstrained households (Gerali et al., 2010). The same ratio is assumed for taxes. The aggregate consumption-output ratio has been set to 0.4 , and the taxes-output ratio to 0.1972 . The ratio of market to non-market activities is set equal to 0.3 , whereas the stock of capital-output ratio to 8 . The steady-state value of the gross money market rate has been chosen equal to 1.015, which implies a gross inflation rate of around 1.004.

Following Gerali et al. (2010), we set $L T V^{C}$ at 0.7 , a value in line with the evidence for mortgages in the euro area reported by Calza et al. (2007). $L T V_{B}^{C B}$ is set at 0.9, consistently with the average levels of valuation haircuts applied by the ECB to eligible marketable central government debt instruments. $L T V_{C}^{C B}$ is assumed to exhibit a lower steady-state value, namely 0.8 . We choose a steady-state value for the housing stock

\footnotetext{
${ }^{14}$ The codes are available upon request as well as the appendices reporting the deterministic steadystate and the log-linearized model.
} 
equal to 1 .

Some parameters are chosen following previous studies and their calibrated value is quite standard in the literature. Among them: the elasticity of substitution across goods $\theta$, set equal to 6 (Schmitt-Grohé and Uribe, 2004); the habit formation parameter $\gamma$, set equal to 0.7 (Smets and Wouters, 2007); the elasticity of intertemporal substitution $\sigma$, set equal to 0.5 , which implies a coefficient of relative risk aversion of 2 ; the depreciation rate of capital $\delta$ calibrated to 0.025 (Christiano et al., 2005; Altig et al., 2011), which implies an annual rate of depreciation on capital equal to 10 percent; the share of capital in the production function $\alpha$, set to 0.36 (Christiano et al., 2005; Altig et al., 2011); the parameter of the price adjustment cost $\phi_{P}$, calibrated to 100 (Ireland, 2004); the elasticity of real money balances $\chi$, set equal to 7 ; the Frisch elasticity $\psi$, set equal to 1 . The discount factor of constrained and unconstrained households is calibrated to 0.9943 and 0.9923 , respectively. The preference parameter of the liquidity aggregator $\eta_{x}$ is set at 0.3 in order to pin down a reasonable steady-state level of deposits and money balances of unconstrained households. The share parameter $v$ in the liquidity aggregator index, which indicate the relative share of money in the liquidity bundle, is set equal to 0.2 (Agénor et al., 2012). The parameters of the fiscal and monetary policy rules are calibrated in a standard way, with $\alpha_{R}$ set equal to $0.7, \alpha_{\pi}$ to $1.5, \alpha_{Y}$ to zero, and $\psi_{1}$ to 0.3 .

The fraction of bank capital reinvested $\phi^{B}$ is assumed to be 0.9 , while the costs of managing loans to households is chosen equal to 0.01. The cost associated with the leverage requirement is set equal to 0.1 (Gerali et al., 2010).

The AR coefficients and the standard deviations of the shocks are set to $\phi_{A}=0.95$, $\phi_{G}=0.90, \sigma_{A}=0.01, \sigma_{R}=0.005, \sigma_{G}=0.012, \sigma_{P^{H}}=0.1$ (see, for example, Christiano and Eichenbaum, 1992; Kim, 2000; Andrés et al., 2004; Altig et al., 2011). $\phi_{P^{H}}$ is set equal to 0.8 after regressing on its first lag actual quarterly data of housing prices in the euro area over the period 2003-2008.

There is little guidance in the literature on how to set the parameters of the LTV ratios and risk weights. Therefore, we adopt the following calibration strategy. We set 
these parameters so as to match actual correlations among LTV ratios and risk weights, and their determinants. In other words, the correlations of our simulated variables have to be approximately identical to the actual ones reported in Table 3, and calculated using euro area data obtained from the ECB Statistical Data Warehouse and Thomson Reuters Datastream. Table 4 reports the resulting calibration for the parameters. We choose the autoregressive parameters by regressing the actual series of our proxies for the LTV ratios on their first lag. The standard deviations of the shocks to the LTV ratios and risk weights have been set equal to 0.1.

Lastly, the values of the remaining parameters and steady-states are computed using the deterministic steady-state solution.

\subsubsection{A Strategy for Modeling the Basel Accords}

Thanks to the novel formulation of the weighted leverage cost, the model allows us to distinguish different prudential regulatory regimes by adequately changing capital requirements and risk weight measures. In the baseline calibration of the model, the economy is assumed to be subjected to a regulatory framework similar to Basel III. Therefore, we set the steady-state ratio of bank capital $Z$ to total assets $\left(B^{B}+L^{C}\right)$ at 0.13 , the value imposed by Basel III. For this purpose, we need to set the cost of managing bank capital $\delta^{b}$ at 0.021 . The other regime considered in the analysis (Basel $I I$ ) requires a leverage ratio equal to 0.08 , which implies $\delta^{b}$ equal to 0.035 .

The parameters of equation (36) and equation (37) are then exploited to further distinguish the different regimes. Besides imposing capital requirements, Basel II strengthened the role of systemic risk in comparison with previous regulatory frameworks. Angelini et al. (2010) and Angelini et al. (2012) model a risk-based Basel II mechanism by introducing time-varying weights expressed as a function of output deviations from the steady-state. The role played by financial intermediaries in the recent financial crisis reinforced the concerns about the inadequacy of risk measures based solely on countercyclical systemic elements. Therefore, authorities proposed a new regulatory regime, Basel III, which in fact considers a wider set of risk-sensitive capital requirements (Basel 
Committee and others, 2009; Basel Committee on Banking Supervision, 2010). The new framework emphasizes even more that the amount of capital banks must hold is also determined by the riskiness of each particular borrower. As the risk of a specific asset increases, banks are forced to hold a larger amount of capital (Aguiar and Drumond, 2007). In light of these considerations, and differently from the model by Angelini et al. (2012), our risk weights depend also on the time-varying riskiness embedded in the balance sheet of banks. As a result, our richer setting is able to capture, at least to a first approximation, the broader definition of risk introduced with Basel III. In particular, including proxies for counterparties' (i.e. households and government) credit risk is a way to model the interrelationship between risk-perception and the risk weights present in the leverage requirement imposed by regulators on financial intermediaries.

In light of these considerations, the Basel II regime is modeled by setting to zero the parameters $\varphi_{1, w^{G}}, \varphi_{1, w^{C}}$ and $\varphi_{2, w^{C}}$. Lastly, a No Basel regime is considered by assuming that risk weights are time-invariant. Table 5 summarizes the calibration strategy chosen for the different regulatory frameworks.

\section{The Results}

As highlighted in previous sections, the model exhibits a quite high degree of complexity. In order to retain tractability, in this paper we focus on a few set of well-defined issues, leaving for future research the study of further questions that may be potentially tackled using this framework. More precisely, in this paper we first show the implications of having endogenous loan-to-value ratios (paragraph 3.1), and then we compare the effectiveness of different prudential regulatory regimes in affecting business cycle fluctuations and restoring macroeconomic and financial stability (paragraph 3.2).

Table 6 reports the shocks present in the model economy, distinguishing between standard macroeconomic shocks, financial shocks and risk weight shocks. This classification is used extensively in the next paragraphs. Figure 2 reports graphically the main channels at work when the economy is hit by a contractionary monetary policy shock. As it can be easily generalized to other types of disturbances, it will guide us throughout the 
following pages.

\subsection{Exogenous vs Endogenous LTV Ratios}

Endogenous and time-varying loan-to-value ratios for households and banks represent one of the salient features of model. Inspired by the empirical evidence, we have derived a novel formulation of LTV ratios that combines both specific risk factors and a countercyclical element. The first issue we need to address regards the implications of the presence of such endogenous constraints for the main dynamics of the model. To this purpose, we report the impulse response functions to standard macroeconomic shocks, comparing the cases of endogenous versus exogenous loan-to-value ratio of households $\left(L T V_{t}^{C}\right){ }^{15}$ We perform this exercise using the baseline calibration, which reflects, as already mentioned, a Basel III scenario. All the impulse response functions reported in the paper represent percentage deviations from the steady-state.

We focus on six main variables: four standard variable that are standard in the literature (total amount of lending to constrained households, lending rate, output and bank equity) and two banking specific variables, which allow us to obtain a deeper insight on the effects of capital regulation on banks' balance sheet. These are the bank leverage, defined as the ratio of assets over equity, and a risk ratio, defined as the ratio of loans to households and bonds held by banks, introduced to better evaluate how the composition of the asset side of banks' balance sheet changes over time.

Figure 3 reports the impulse response functions to a contractionary monetary policy shock. In line with standard DSGE models, an exogenous increase in the policy rate causes a negative effect on investment, which leads to a contraction of output. However, within this setting, we have further channels through which a monetary policy shock propagates to the economy. In particular, we observe a reduction in the total amount of loans to constrained households due to the combined effect of a higher lending rate and lower housing prices. Since banks are subject to a leverage cost, the drop in households

\footnotetext{
${ }^{15}$ Exogenous refers to $L T V_{t}^{C}$ following a simple AR process of order 1 . In other words, $\varphi_{1, H}=\varphi_{2, H}=$ $\varphi_{3, H}=0$. The graphs relative to the other shocks and to banking loan-to-value ratios $\left(L T V_{B, t}^{C B}\right.$ and $\left.L T V_{C, t}^{C B}\right)$ are available upon request.
} 
lending leads banks to increase their holding of government bonds. As a result, the risk ratio exhibits a substantial decrease, whereas bank capital increases by around 0.6 percent.

Visual inspection of Figures 3 also suggests that modeling endogenous variations of $L T V_{C, t}$ (blue dashed line) amplifies the effects of a contractionary monetary policy shock. Worsened economic conditions increase the collateral requirement for constrained households, i.e. their borrowing capacity is reduced. More specifically, downward movements in output, house prices and wages generate an endogenous reduction in the LTV of constrained households, which magnifies the drop in total lending. Thus, these findings show that the model is able to reproduce a realistic situation, in which worsened credit market conditions arise from an endogenous tightening of lending requirements.

Turning to a positive technology innovation (Figure 4), it is possible to observe in both cases an increase in real output and better credit conditions for households due to a lower interest rate on loans. With endogenous collateral constraints, the overall improvement of both households' idiosyncratic conditions and general economic outlook looses the collateral requirement of constrained households, generating a substantially larger increase in the amount of loans provided by banks to households. As a consequence, also the exposure of banks (i.e. ratio risk) exhibits a larger increase. The procyclical dynamics of credit are thus amplified.

Monetary and technology shocks feature procyclical lending, and, therefore, endogenous LTV ratios generate an amplification effect for credit conditions. However, a government spending shock (Figure 5) leads to a general increase in interest rates, which, in turn, causes a fall in loans to households. In this case, lending is anticyclical, and the presence of a time-varying constraint mitigates the negative effect on total loan quantities. In particular, the lower value of the collateral needed by households reflects the overall improvement of the economic conditions following an expansionary fiscal policy shock. The smaller reduction in lending leads to lower volatility also in the asset side composition of banks.

These findings clearly indicate that the presence of endogenous LTV ratios exacerbates 
the procyclicality of lending conditions, revealing that our model exhibits better business cycle properties compared to similar settings with exogenous LTV ratios. The greater volatility generated within our setting would require in principle incisive countercyclical measures to prevent excessive fluctuations of business cycles. These issues are partially covered in the next paragraphs.

\subsection{Comparing No Basel with Basel III}

In this sub-section we compare the results of our baseline model, which reflects a Basel III regime, and those obtained from a specification still featuring endogenous constraints, but no capital requirement and risk weight measures (labeled $\mathrm{No} \mathrm{Basel}$ ). Figures 6-8 plot the impulse response functions to the three standard macroeconomic shocks. First of all, it should be noted that the difference in the prudential regimes does not reflect any substantial dissimilarity in the response of output. The negligible impact on the macroeconomy is consistent with the findings of other studies (De Walque et al., 2010; Angelini et al., 2010, 2012), and in this model is probably exacerbated by the absence of borrowing firms.

In addition, we find that the presence of a prudential regime like Basel III increases the procyclical nature of credit. The procyclicality of risk-based capital regulatory frameworks is well documented in the literature (Aguiar and Drumond, 2007; Angelini et al., 2010; Pariès et al., 2011), ${ }^{16}$ and is due to the fact that credit risk itself is procyclical. Our simulated Basel III regime amplifies the response of the quantity of total lending to households after a shock in all three cases. By contrast, Basel III is effective in dampening the volatility of both the risk- and leverage position of banks in comparison with the No Basel regime. Following a contractionary monetary policy shock (Figure $6)$, the combination of tighter capital requirements and worsening economic conditions (which increases the riskiness of banks' assets) forces banks to reduce their leverage ratio generating a deeper contraction in the loan supply. The resulting reduction in the size of the asset side of banks' balance sheet leads banks to raise aggressively the lending

\footnotetext{
${ }^{16}$ See Drumond (2009) for a review of the most recent studies.
} 
rate. Higher borrowing costs faced by constrained households contribute eventually to increase banks' net worth. The key role played by time-varying risk weights is confirmed by considering the responses to productivity and government spending shocks (Figure 7 and Figure 8, respectively). In the first case, for instance, improved economic conditions induce risk weights to decline, making loans less risky. In order to meet the required leverage ratio, banks have to further expand loan supply by reducing the interest rate on loans. These findings corroborate the hypothesis that risk-based capital requirements, as those proposed by Basel III, sharpen the procyclical nature of credit when the economy is mainly affected by standard macroeconomic shocks. The countercyclical risk weights induce financial intermediaries to hold excessive equity during economic contractions and too less during economic expansions.

We then investigate the properties of the two regulatory frameworks by observing the patterns of the impulse response functions to two financial shocks, namely a credit crunch shock and a negative housing price shock. The first one, adopted following Andrés and Arce (2012), consists in an exogenous shock to the pledgeability ratio $L T V_{t}^{C}$ that reduces the borrowing capacity of households. The second shock is an exogenous negative disturbance on house prices: since the real value of houses is used by households as collateral, a decrease in the price of houses leads to a reduction in the quantity of loans that households are able to receive from banks. Thus, the effects of the two shocks are expected to be qualitatively very similar. Figure 9 and Figure 10 report the impulse response functions.

In line with what found for macroeconomic shocks, the volatility of the risk- and leverage position of banks is substantially lower under a Basel III regime. However, the other results are in sharp contrast with those obtained observing the economy reacting to standard macroeconomic shocks. In fact, now Basel III seems to be capable of mitigating significantly the negative response of both output and lending quantity. The higher capital requirements and the broader set of risk proxies provided for by Basel III reduce the negative spillovers from the financial sector to the economy. The intuition is as follows. Unlike standard macroeconomic shocks, financial shocks have a direct impact 
on the quantity of loans. The immediate reduction of credit to households induces risk weights to decrease, given that the exposure of households and banks decreases and more than offsets the reduction in aggregate output. Since loans are now less risky, to satisfy the imposed capital requirements the reduction of loan supply has not to be as substantial as in the No Basel case. The gains from having a mitigated effect on credit is paid for by higher volatility of the interest rate on loans.

Lastly, we compare the standard deviation of the simulated variables of the baseline model and the specification No Basel. The third, fifth and seventh columns of Table 7 report the standard deviation ratios of the simulated variables when using, respectively, all the shocks present in the model, only the macro shocks, and only the financial shocks. The numbers are computed as the standard deviation implied by Basel III divided by the standard deviation generated by No Basel. Thus, a value larger (smaller) than one indicates that the volatility of the simulated variables under the Basel III regime is larger (smaller) than that obtained under a No Basel framework. The results confirm that when the economy is hit by all the shocks, Basel III increases the volatility of lending and output compared with the case without prudential regulations. Not surprisingly, the same considerations hold when the economy is affected only by standard macroeconomic shocks. However, in a situation in which only financial shocks are at work, namely when the economy is in a period of financial stress, Basel III is effective in downsizing substantially the volatility of loan quantity and output. The fact that risk-based prudential regulations seem to work properly only during periods of extraordinary financial stress is consistent with the results of Angelini et al. (2012).

\subsection{Comparing Basel II with Basel III}

We now compare the baseline regulatory framework Basel III with its predecessor Basel $I I$, as specified in sub-section 2.7.1. The impulse response functions of the three standard macroeconomic shocks (Figures 11-13) indicate that Basel III is able to generate a lower volatility in the risk- and leverage position of banks than Basel II. As far as the remaining variables are concerned, the responses of the two regimes are very close and, in the case 
of a positive technology shock, even amplified under Basel III, suggesting that Basel III may potentially be more procyclical than Basel II during normal times. This can be attributed to the presence of additional risk weight proxies in the Basel III specification, which reinforce the fluctuations of risk associated with loans to households.

The ratios of the standard deviation of the simulated variables under the regime Basel II with respect to the No Basel case are reported in the second, fourth and sixth columns of Table $7 .{ }^{17}$ The findings corroborate the idea that, regardless of the type of shocks hitting the economy, Basel III amplifies the volatility of loan quantities in comparison with Basel II, whereas mitigates the fluctuations in aggregate output and the risk- and leverage position of banks. The magnitude of these differences is nevertheless relatively small.

These results are confirmed, and, to some extent, strengthened when we add to the simulation exercise the two risk weight shocks, which increase exogenously the risk perception of loans to households $\left(w^{C}\right)$ and government bonds $\left(w^{G}\right)$. Table 8 shows the standard deviation ratios of Basel III with respect to Basel II. As in the previous paragraph, a value larger than unity indicates that the volatility of the simulated variable under Basel III is higher than under Basel II. The main conclusion that can be drawn from this analysis is that a regulatory regime like Basel III seems to be generally more effective than Basel II in reducing the volatility of aggregate output and the risk- and leverage position of banks, whereas Basel II is able to stabilize more incisively credit fluctuations.

\section{Concluding Remarks}

This paper provides a new theoretical framework to study the interactions between financial markets and the rest of the economy. The model formalizes the ideas that banking assets are risky and LTV ratios are not constant and depend on systemic factors and leverage conditions of households and banks. Hence, the model is capable of a) reproducing in

\footnotetext{
${ }^{17}$ The impulse responses to financial and risk weight shocks are not reproduce herein, but are available upon request.
} 
a realistic way credit procyclical properties; b) distinguishing different prudential regulatory frameworks by modifying the configuration of the key parameters and steady-states of the model.

The results of our study indicate that endogenous LTV ratios magnify the effect of procyclical lending, and thus the effects of a simulated credit crunch. We have also shown the implications of different prudential regulatory measures. When standard macro shocks prevail (i.e. in normal times), prudential regulatory frameworks such as Basel $I I$ and Basel III increase the volatility of credit and macroeconomic variables. When financial shocks prevail (i.e. in periods of extraordinary financial stress) Basel II and Basel III contribute substantially to stabilize credit markets and the overall economy. Moreover, Basel III is generally more effective in doing so than Basel II. These findings are very important for policy-makers struggling to find effective tools to smooth business cycle fluctuations and restore macroeconomic and financial stability. 


\section{References}

Adjemian, S., Bastani, H., Juillard, M., Mihoubi, F., Perendia, G., Ratto, M., and Villemot, S. (2011). Dynare: Reference manual, version 4. Dynare Working Papers 1, CEPREMAP.

Adrian, T. and Shin, H. S. (2010a). Financial intermediaries and monetary economics. In Friedman, B. M. and Woodford, M., editors, Handbook of Monetary Economics, volume 3, chapter 12, pages 601-650. Elsevier.

Adrian, T. and Shin, H. S. (2010b). Liquidity and leverage. Journal of Financial Intermediation, 19(3):418-437.

Agénor, P.-R., Alper, K., and da Silva, L. P. (2012). Capital requirements and business cycles with credit market imperfections. Journal of Macroeconomics, 34(3):687-705.

Aguiar, A. and Drumond, I. (2007). Business cycle and bank capital: Monetary policy transmission under the Basel Accords. FEP Working Papers 242, Universidade do Porto, Faculdade de Economia do Porto.

Altig, D., Christiano, L. J., Eichenbaum, M., and Lind, J. (2011). Firm-specific capital, nominal rigidities and the business cycle. Review of Economic Dynamics, 14(2):225247.

Andrés, J. and Arce, O. (2012). Banking competition, housing prices and macroeconomic stability. The Economic Journal, IN PRESS.

Andrés, J., López-Salido, J. D., and Nelson, E. (2004). Tobin's imperfect asset substitution in optimizing general equilibrium. Journal of Money, Credit and Banking, 36(4):665-690.

Angelini, P., Clerc, L., Cúrdia, V., Gambacorta, L., Gerali, A., Locarno, A., Motto, R., Roeger, W., den Heuvel, S. V., and Vlcek, J. (2011). BASEL III: Long-term impact on economic performance and fluctuations. BIS Working Papers 338, Bank for International Settlements. 
Angelini, P., Enria, A., Neri, S., Panetta, F., and Quagliariello, M. (2010). Pro-cyclicality of capital regulation: Is it a problem? How to fix it? Questioni di Economia e Finanza (Occasional Papers) 74, Bank of Italy, Economic Research and International Relations Area.

Angelini, P., Neri, S., and Panetta, F. (2012). Monetary and macroprudential policies. Working Paper Series 1449, European Central Bank.

Angeloni, I. and Faia, E. (2013). Capital regulation and monetary policy with fragile banks. Journal of Monetary Economics, 60(3):311-324.

Aoki, K., Proudman, J., and Vlieghe, G. (2004). House prices, consumption, and monetary policy: a financial accelerator approach. Journal of Financial Intermediation, 13(4):414-435.

Basel Committee and others (2009). Strengthening the resilience of the banking sector. Consultative document, BIS.

Basel Committee on Banking Supervision (2010). Basel III: International framework for liquidity risk measurement, standards and monitoring. Bank for International Settlements.

Beau, D., Clerc, L., and Mojon, B. (2012). Macro-prudential policy and the conduct of monetary policy. Working papers 390, Banque de France.

Bernanke, B. and Gertler, M. (1989). Agency costs, net worth, and business fluctuations. The American Economic Review, 79(1):14-31.

Bernanke, B. S., Gertler, M., and Gilchrist, S. (1996). The financial accelerator and the flight to quality. The Review of Economics and Statistics, 78(1):1-15.

Bernanke, B. S., Gertler, M., and Gilchrist, S. (1999). The financial accelerator in a quantitative business cycle framework. In Taylor, J. B. and Woodford, M., editors, Handbook of Macroeconomics, chapter 21, pages 1341-1393. Elsevier. 
Calza, A., Monacelli, T., and Stracca, L. (2007). Mortgage markets, collateral constraints, and monetary policy: Do institutional factors matter? CFS Working Paper Series 2007/10, Center for Financial Studies.

Campbell, J. and Cocco, J. (2011). A model of mortgage default. Working Paper 17516, National Bureau of Economic Research.

Canzoneri, M. B., Cumby, R., Diba, B. T., and López-Salido, D. (2008). Monetary aggregates and liquidity in a neo-wicksellian framework. Journal of Money, Credit and Banking, 40(8):1667-1698.

Canzoneri, M. B., Cumby, R., Diba, B. T., and López-Salido, D. (2011). The role of liquid government bonds in the great transformation of American monetary policy. Journal of Economic Dynamics and Control, 35(3):282 - 294.

Christensen, I. and Dib, A. (2008). The financial accelerator in an estimated New Keynesian model. Review of Economic Dynamics, 11(1):155-178.

Christiano, L. J. and Eichenbaum, M. (1992). Current real-business-cycle theories and aggregate labor-market fluctuations. The American Economic Review, 82(3):430-450.

Christiano, L. J., Eichenbaum, M., and Evans, C. L. (2005). Nominal rigidities and the dynamic effects of a shock to monetary policy. Journal of Political Economy, 119(1):145.

Christiano, L. J., Motto, R., and Rostagno, M. (2003). The great depression and the Friedman-Schwartz hypothesis. Journal of Money, Credit, and Banking, 35(6):11191197.

Christiano, L. J., Motto, R., and Rostagno, M. (2008). Shocks, structures or monetary policies? The Euro area and US after 2001. Journal of Economic Dynamics and Control, 32(8):2476-2506.

Christiano, L. J., Motto, R., and Rostagno, M. (2010). Financial factors in economic fluctuations. Working Paper Series 1192, European Central Bank. 
Christoffel, K., Coenen, G., and Warne, A. (2008). The new area-wide model of the euro area - A micro-founded open-economy model for forecasting and policy analysis. Working Paper Series 944, European Central Bank.

De Walque, G., Pierrard, O., and Rouabah, A. (2010). Financial (in)stability, supervision and liquidity injections: A dynamic general equilibrium approach. The Economic Journal, 120(549):1234-1261.

den Heuvel, S. J. V. (2008). The welfare cost of bank capital requirements. Journal of Monetary Economics, 55(2):298-320.

Dib, A. (2010). Banks, credit market frictions, and business cycles. Bank of Canada Working Papers 24.

Dixit, A. K. and Stiglitz, J. E. (1977). Monopolistic competition and optimum product diversity. The American Economic Review, 67(3):297-308.

Drumond, I. (2009). Bank capital requirements, business cycle fluctuations and the basel accords: a synthesis. Journal of Economic Surveys, 23(5):798-830.

Forlati, C. and Lambertini, L. (2011). Risky mortgages in a DSGE model. International Journal of Central Banking, 31(1):3228-54.

Galati, G. and Moessner, R. (2012). Macroprudential policy - A literature review. Journal of Economic Surveys, pages -.

Gerali, A., Neri, S., Sessa, L., and Signoretti, F. M. (2010). Credit and banking in a DSGE model of the Euro Area. Journal of Money, Credit and Banking, 42:107-141.

Gertler, M., Gilchrist, S., and Natalucci, F. M. (2007). External constraints on monetary policy and the financial accelerator. Journal of Money, Credit and Banking, 39(23):295-330. 
Gruss, B. and Sgherri, S. (2009). The volatility costs of procyclical lending standards: An assessment using a DSGE model. IMF Working Papers 09/35, International Monetary Fund.

Iacoviello, M. (2005). House prices, borrowing constraints, and monetary policy in the business cycle. The American Economic Review, 95(3):739-764.

Iacoviello, M. and Neri, S. (2010). Housing market spillovers: Evidence from an estimated DSGE model. American Economic Journal: Macroeconomics, 2(2):125-64.

Ireland, P. N. (2004). Money's role in the monetary business cycle. Journal of Money, Credit and Banking, 36(6):969-83.

Jaffee, D. M. and Russell, T. (1976). Imperfect information, uncertainty, and credit rationing. The Quarterly Journal of Economics, 90(4):651-666.

Kim, J. (2000). Constructing and estimating a realistic optimizing model of monetary policy. Journal of Monetary Economics, 45(2):329-359.

Kiyotaki, N. and Moore, J. (1997). Credit cycles. The Journal of Political Economy, 105(2):211-248.

Lambertini, L., Mendicino, C., and Punzi, M. T. (2011). Leaning against boom-bust cycles in credit and housing prices. Working Papers 201101, Center for Fiscal Policy, Swiss Federal Institute of Technology Lausanne.

Leeper, E. M. (1991). Equilibria under active and passive monetary and fiscal policies. Journal of Monetary Economics, 27(1):129-147.

Lombardo, G. and McAdam, P. (2012). Financial market frictions in a model of the Euro area. Economic Modelling, 29(6):2460-2485.

Meh, C. A. and Moran, K. (2010). The role of bank capital in the propagation of shocks. Journal of Economic Dynamics and Control, 34(3):555-576. 
Mendoza, E. G. (2010). Sudden stops, financial crises, and leverage. The American Economic Review, 100(5):1941-1966.

Pariès, M. D., Sørensen, C. K., and Rodriguez-Palenzuela, D. (2011). Macroeconomic propagation under different regulatory regimes: Evidence from an estimated DSGE model for the euro area. International Journal of Central Banking, 7(4):49-113.

Roger, S. and Vlček, J. (2011). Macroeconomic costs of higher bank capital and liquidity requirements. IMF Working Paper 11/103, International Monetary Fund.

Roger, S. and Vlcek, J. (2012). Macrofinancial modeling at central banks: Recent developments and future directions. IMF Working Papers 12/21, International Monetary Fund.

Rotemberg, J. J. (1982). Monopolistic price adjustment and aggregate output. The Review of Economic Studies, 49(4):517-531.

Schmitt-Grohé, S. and Uribe, M. (2004). Optimal fiscal and monetary policy under imperfect competition. Journal of Macroeconomics, 26(2):183-209.

Smets, F. and Wouters, R. (2003). An estimated dynamic stochastic general equilibrium model of the Euro area. Journal of the European Economic Association, 1(5):11231175 .

Smets, F. and Wouters, R. (2007). Shocks and frictions in us business cycles: A bayesian DSGE approach. The American Economic Review, 97(3):586-606.

Stiglitz, J. E. and Weiss, A. (1981). Credit rationing in markets with imperfect information. The American Economic Review, 71(3):393-410.

Taylor, J. B. (1993). Discretion versus policy rules in practice. Carnegie-Rochester Conference Series on Public Policy, 39:195-214.

Zhang, L. (2009). Bank capital regulation, the lending channel and business cycles. Discussion Paper Series 1: Economic Studies 33, Deutsche Bundesbank, Research Centre. 


\section{Tables}

Table 1: Steady-state values

\begin{tabular}{clc}
\hline \hline Notation & \multicolumn{1}{c}{ Description } & SS values \\
\hline$Y$ & Output & 1 \\
$L /(1-L)$ & Ratio of market to non-market activities & 0.3 \\
$K / Y$ & Stock of capital-GDP ratio & 8 \\
$C / Y$ & Total consumption-GDP ratio & 0.4 \\
$C^{C} / Y$ & Consumption-GDP ratio CH & $0.1 * C$ \\
$C^{U} / Y$ & Consumption-GDP ratio UH & $0.9 * C$ \\
$T / Y$ & Taxes-GDP ratio & 0.1972 \\
$T^{C} / Y$ & Taxes-GDP ratio CH & $0.1 * T$ \\
$T^{U} / Y$ & Taxes-GDP ratio UH & $0.9 * T$ \\
$R^{C B}$ & Gross money-market rate & 1.015 \\
$L T V$ & Loan-to value ratio households & 0.7 \\
$L T V_{B}^{C B}$ & Loan-to value ratio banks - gov. bonds & 0.9 \\
$L T V_{C}^{C B}$ & Loan-to value ratio banks - loans to HH & 0.8 \\
$H$ & Stock of housing & 1 \\
\hline
\end{tabular}

Notes: CH indicates constrained households; UH indicates unconstrained households. 
Table 2: Benchmark calibration of the standard parameters (Basel III)

\begin{tabular}{|c|c|c|}
\hline Notation & Description & Benchmark values \\
\hline & Preferences and technology & \\
\hline$\alpha$ & Share of capital in the production function & 0.36 \\
\hline$\beta_{C}$ & Intertemporal discount factor of $\mathrm{CH}$ & 0.9943 \\
\hline$\beta_{U}$ & Intertemporal discount factor of UH & 0.9923 \\
\hline$\sigma$ & Elasticity of intertemporal substitution & 0.5 \\
\hline$\chi$ & Elasticity of money demand & 7 \\
\hline$\psi$ & Elasticity of labor supply & 1 \\
\hline$\gamma$ & Habit formation & 0.7 \\
\hline$\theta$ & Elasticity of substitution between varieties of goods & 6 \\
\hline$\phi_{P}$ & Price adjustment costs & 100 \\
\hline$v$ & Elasticity of money in the liquidity aggregator & 0.2 \\
\hline$\eta_{x}$ & Elasticity of liquidity in the utility function of UH & 0.3 \\
\hline & Fiscal and monetary policy & \\
\hline$\psi_{0}$ & Fiscal policy constant & 0.1972 \\
\hline$\psi_{1}$ & Fiscal policy response to $b$ & 0.3 \\
\hline$\alpha_{\pi}$ & Monetary policy response to inflation & 1.5 \\
\hline$\alpha_{Y}$ & Monetary policy response to output & 0 \\
\hline$\alpha_{R}$ & Monetary policy inertia & 0.7 \\
\hline & Banking sector & \\
\hline$\delta^{b}$ & Cost of managing bank capital & 0.021 \\
\hline$\phi^{B}$ & Profits reinvested in bank capital & 0.9 \\
\hline$\gamma^{C}$ & Cost of managing loans & 0.01 \\
\hline$e$ & Leverage ratio cost & 0.1 \\
\hline & Autoregressive parameters & \\
\hline$\phi_{A}$ & Technology shock & 0.95 \\
\hline$\phi_{G}$ & Government spending shock & 0.90 \\
\hline$\phi_{P^{H}}$ & Housing prices shock & 0.80 \\
\hline & Standard deviations & \\
\hline$\sigma_{A}$ & Technology shock & 0.01 \\
\hline$\sigma_{G}$ & Government spending shock & 0.012 \\
\hline$\sigma_{R}$ & Monetary policy shock & 0.005 \\
\hline$\sigma_{P H}$ & Housing prices shock & 0.1 \\
\hline
\end{tabular}

Notes: CH indicates constrained households; UH indicates unconstrained households. 
Table 3: Actual correlations between LTVs and risk weights and their determinants

\begin{tabular}{cccccc}
\hline \hline & $L T V_{t}^{C}$ & $L T V_{B, t}^{C B}$ & $w_{t}^{G}$ & $L T V_{C, t}^{C B}$ & $w_{t}^{C}$ \\
\hline$P_{t}^{H}$ & 0.624 & - & - & - & - \\
$w_{t} F_{t}$ & 0.576 & - & - & - & - \\
$Y_{t}$ & 0.716 & 0.441 & -0.441 & 0.702 & -0.702 \\
$B_{t}$ & - & -0.286 & 0.286 & - & - \\
$\left(L_{t}^{C} R_{t}^{C}\right) / P_{t}^{H}$ & - & - & - & 0.578 & -0.578 \\
$L_{t}^{C} / D_{t}$ & - & - & - & 0.442 & - \\
$L_{t}^{C} / Z_{t}$ & - & - & - & - & -0.208 \\
\hline
\end{tabular}

Sources: Authors' elaborations on data from the ECB Statistical Data Warehouse and Datastream. Notes: All the variables are expressed as quarterly percentage changes over the period 2003-2012 (except for $L T V_{B . t}^{C B}$, which is only available from 2008). $L T V_{t}^{C}$ is proxied by the opposite of the net percentage of banks reporting a tightening of the loan-to-value ratio of loans for house purchases over the previous quarter (Question 10 of the Bank Lending Survey). $w_{t}^{G}$ is proxied by the sovereign CDS spread of Germany. $w_{t}^{C}$ is proxied by the net percentage of banks reporting a tightening of collateral requirements for loans for house purchases over the previous quarter (Question 10 of the Bank Lending Survey). $L T V_{B, t}^{C B}$ and $L T V_{C, t}^{C B}$ are the opposite of $w_{t}^{G}$ and $w_{t}^{C}$, respectively. $P_{t}^{H}$ is residential property prices of new and existing dwellings. $w_{t}$ is hourly compensation. $F_{t}$ is total employment in hours. $Y_{t}$ is GDP at market price. $B_{t}$ is general government debt. $L_{t}^{C}$ is lending for house purchase (over five years). $R_{t}^{C}$ is the interest rate on loans for house purchase. $D_{t}$ is deposit liabilities. $Z_{t}$ is capital and reserves. For the computation of the correlations, the quantity of housing $h_{t}$ has been considered fixed.

Table 4: Benchmark calibration of the parameters of LTV ratios and risk weights

\begin{tabular}{|c|c|c|c|}
\hline \multirow[t]{2}{*}{ Notation } & \multirow[t]{2}{*}{ Description } & \multicolumn{2}{|c|}{ Benchmark values } \\
\hline & & Exog. LTVs & Endog. LTVs \\
\hline & $L T V_{t}^{C}$ & & \\
\hline$\varphi_{1, H}$ & Elasticity of $L T V_{t}^{C}$ wrt the value of housing & - & 0.02 \\
\hline$\varphi_{2, H}$ & Elasticity of $L T V_{t}^{C}$ wrt to labor income & - & 0.02 \\
\hline$\varphi_{3, H}$ & Elasticity of $L T V_{t}^{C}$ wrt to output & - & 2 \\
\hline$\phi_{L T V^{C}}$ & AR parameter & - & 0.8 \\
\hline & $L T V_{B, t}^{C B}$ & & \\
\hline$\varphi_{1, B}$ & Elasticity of $L T V_{B, t}^{C B}$ wrt total government debt & - & -0.2 \\
\hline$\varphi_{2, B}$ & Elasticity of $L T V_{B, t}^{C L}$ wrt output & - & 0.5 \\
\hline$\phi_{L T V_{B}^{C B}}$ & AR parameter & - & 0.2 \\
\hline & $L T V_{C, t}^{C B}$ & & \\
\hline$\varphi_{1, C}$ & Elasticity of $L T V_{C, t}^{C B}$ wrt the ratio value of loans-value of housing & - & -0.01 \\
\hline$\varphi_{2, C}$ & Elasticity of $L T V_{C, t}^{C L B}$ wrt the loan-to-deposit ratio & - & -0.005 \\
\hline$\varphi_{3, C}$ & Elasticity of $L T V_{C, t}^{C B}$ wrt output & - & 2 \\
\hline$\phi_{L T V_{C}^{C B}}$ & AR parameter & - & 0.8 \\
\hline & Sovereign bond risk $w_{t}^{G}$ & & \\
\hline$\varphi_{1, w^{G}}$ & Elasticity of $w_{t}^{G}$ wrt total government debt & 0.25 & 0.25 \\
\hline$\varphi_{2, w^{G}}$ & Elasticity of $w_{t}^{G}$ wrt output & -0.5 & -0.5 \\
\hline$\phi_{w^{G}}$ & AR parameter & 0.2 & 0.2 \\
\hline & Households' loans risk $w_{t}^{C}$ & & \\
\hline$\varphi_{1, w C}$ & Elasticity of $w_{t}^{C}$ wrt the ratio value of loans-value of housing & 0.01 & 0.01 \\
\hline$\varphi_{2, w} C$ & Elasticity of $w_{t}^{C}$ wrt the loans to capital ratio & 0.01 & 0.01 \\
\hline$\varphi_{3, w} C$ & Elasticity of $w_{t}^{C}$ wrt output & -2 & -2 \\
\hline$\phi_{w} C$ & AR parameter & 0.8 & 0.8 \\
\hline & Standard deviations & & \\
\hline$\sigma^{L T V^{C}}$ & Shock to $L T V_{t}^{C}$ & 0.1 & 0.1 \\
\hline$\sigma^{w^{G}}$ & Shock to $w_{t}^{G}$ & 0.1 & 0.1 \\
\hline
\end{tabular}


Table 5: Model specifications of the Basel Accords

\begin{tabular}{|c|c|c|c|c|c|c|}
\hline \multirow[b]{2}{*}{$\downarrow$ Regime } & \multirow[b]{2}{*}{$\frac{Z}{L^{C}+B^{B}}$} & \multicolumn{2}{|c|}{$w_{t}^{G}$} & \multicolumn{3}{|c|}{$w_{t}^{C}$} \\
\hline & & $\varphi_{1, w^{G}}$ & $\varphi_{2, w^{G}}$ & $\varphi_{1, w^{C}}$ & $\varphi_{2, w^{C}}$ & $\varphi_{3, w^{C}}$ \\
\hline No Basel & No min. req. & $\mathrm{x}$ & $\mathrm{x}$ & $\mathrm{x}$ & $\mathrm{x}$ & $\mathrm{x}$ \\
\hline Basel II & 0.08 & $\mathrm{x}$ & $\checkmark$ & $\mathrm{x}$ & $\mathrm{x}$ & $\checkmark$ \\
\hline Basel III & 0.13 & $\checkmark$ & $\checkmark$ & $\checkmark$ & $\checkmark$ & $\checkmark$ \\
\hline
\end{tabular}

Table 6: Classification of shocks

\begin{tabular}{llllll}
\hline \multicolumn{2}{c}{ Macroeconomic shocks } & & \multicolumn{1}{c}{ Financial shocks } & \multicolumn{2}{c}{ Risk weight shocks } \\
\hline$\varepsilon^{A}$ & Technology shock & $\varepsilon^{L T V^{C}}$ & Credit crunch shock & $\varepsilon^{w^{C}}$ & MBS risk shock \\
$\varepsilon^{R}$ & Monetary policy shock & $\varepsilon^{L T V_{B}^{C B}}$ & Sovereign debt downgrading shock & $\varepsilon^{w^{G}}$ & Sovereign risk shock \\
$\varepsilon^{G}$ & Government spending shock & $\varepsilon^{L T V_{B}^{C B}}$ & MBS downgrading shock & & \\
& & $\varepsilon^{P^{H}}$ & Housing prices shock & \\
\hline
\end{tabular}

Table 7: Standard deviation of the simulated variables without risk weight shocks

\begin{tabular}{|c|c|c|c|c|c|c|}
\hline \multirow[b]{2}{*}{ Endog. LTVs } & \multicolumn{2}{|c|}{ All shocks } & \multicolumn{2}{|c|}{ Only macro shocks } & \multicolumn{2}{|c|}{ Only financial shocks } \\
\hline & BII & BIII & BII & BIII & BII & BIII \\
\hline$L_{t}^{C}$ & 1.234 & 1.327 & 1.294 & 1.406 & 0.772 & 0.809 \\
\hline$L_{t}^{C} / B_{t}^{B}$ & 1.523 & 0.901 & 2.164 & 1.374 & 0.490 & 0.245 \\
\hline$\left(L_{t}^{C}+B_{t}^{B}\right) / Z_{t}$ & 0.081 & 0.045 & 0.080 & 0.043 & 0.003 & 0.026 \\
\hline$\underline{Y_{t}}$ & 1.054 & 1.045 & 1.011 & 1.002 & 0.643 & 0.561 \\
\hline
\end{tabular}

Notes: Standard deviation ratios of Basel II and Basel III with respect to No Basel $\left(S D_{B I I} / S D_{N B}, S D_{B I I I} / S D_{N B}\right)$.

Table 8: Standard deviation of the simulated variables with risk weight shocks

\begin{tabular}{lcccc}
\hline \hline & All shocks & Macro + Weights shocks & Financial + Weights shocks & Only weights shocks \\
Endog. LTVs & BIII & BIII & BIII & BIII \\
\hline$L_{t}^{C}$ & 1.048 & 1.184 & 1.020 & 1.271 \\
$L_{t}^{C} / B_{t}^{B}$ & 0.526 & 0.673 & 0.496 & 0.458 \\
$\left(L_{t}^{C}+B_{t}^{B}\right) / Z_{t}$ & 0.519 & 0.548 & 0.533 & 0.517 \\
$Y_{t}$ & 0.982 & 1.056 & 0.902 & 0.947 \\
\hline
\end{tabular}

Notes: Standard deviation ratios of Basel III with respect to Basel II $\left(S D_{B I I I} / S D_{B I I}\right)$. 


\section{Figures}

Figure 1: Graphical illustration of the main connections of the model

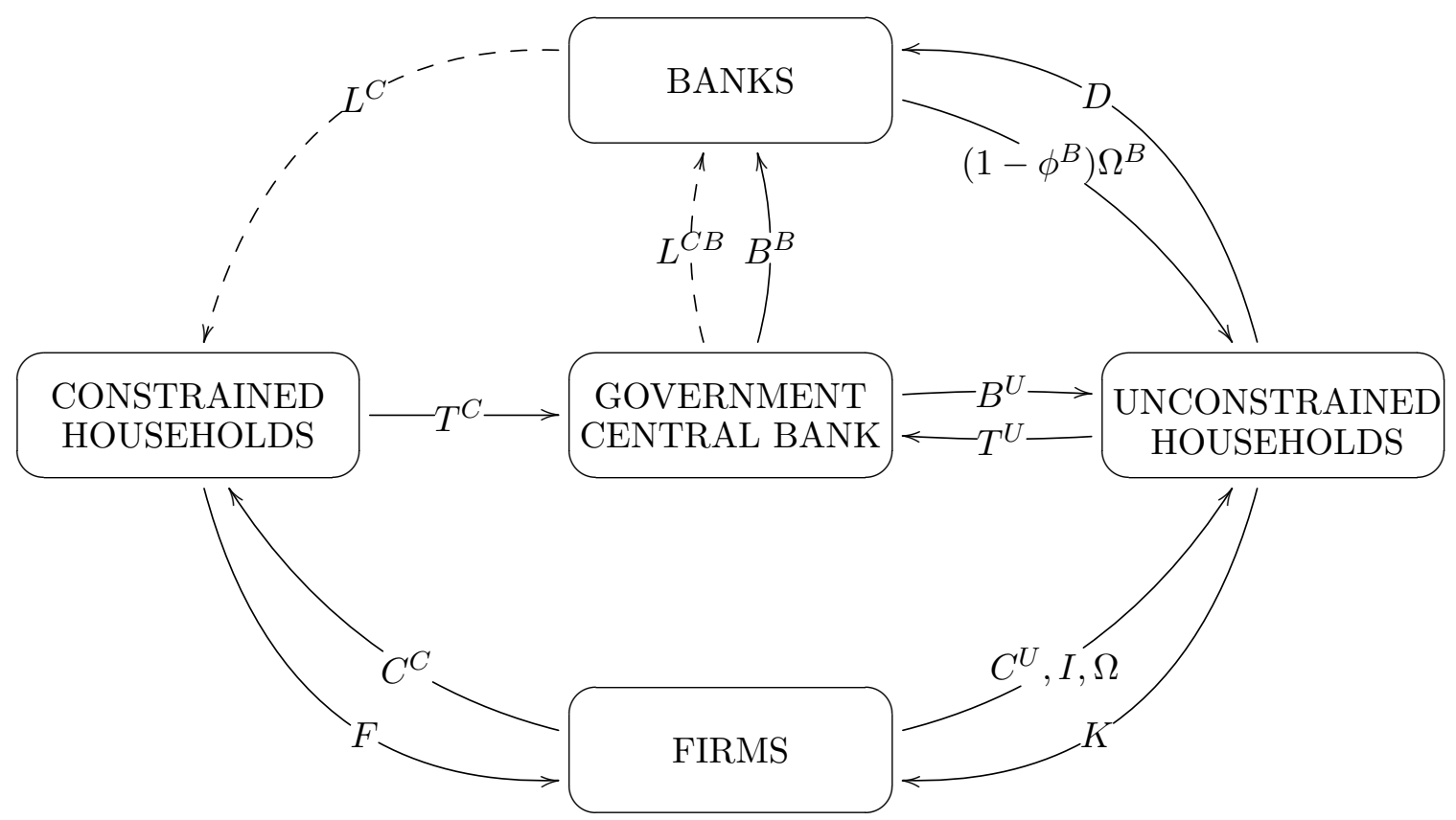

Notes: Dashed arrows indicate connections subjected to borrowing constraints.

Figure 2: The effects of a contractionary monetary policy shock

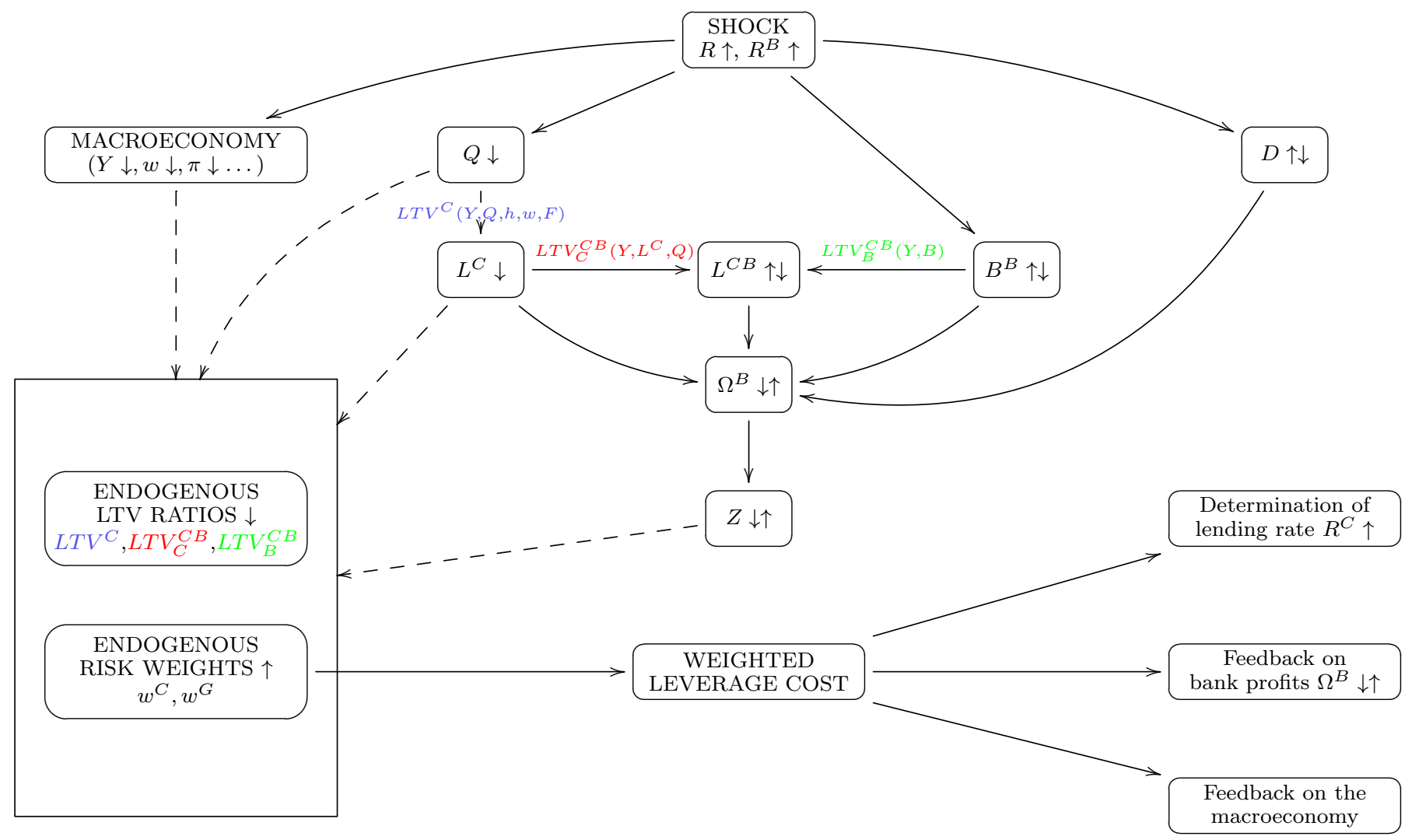


Figure 3: Impulse response functions to a contractionary monetary policy shock
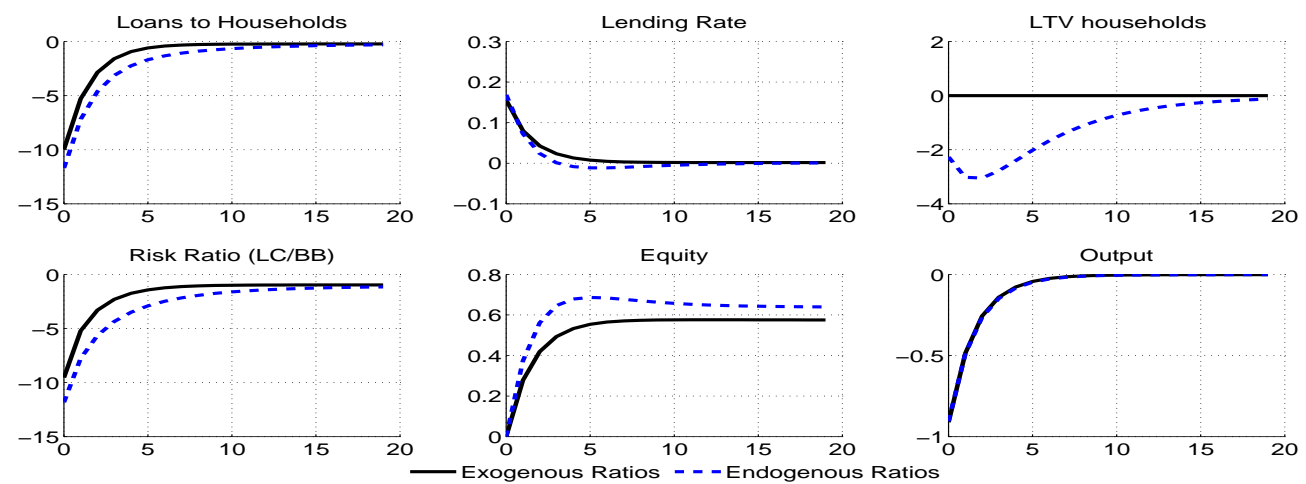

Figure 4: Impulse response functions to a positive technology shock
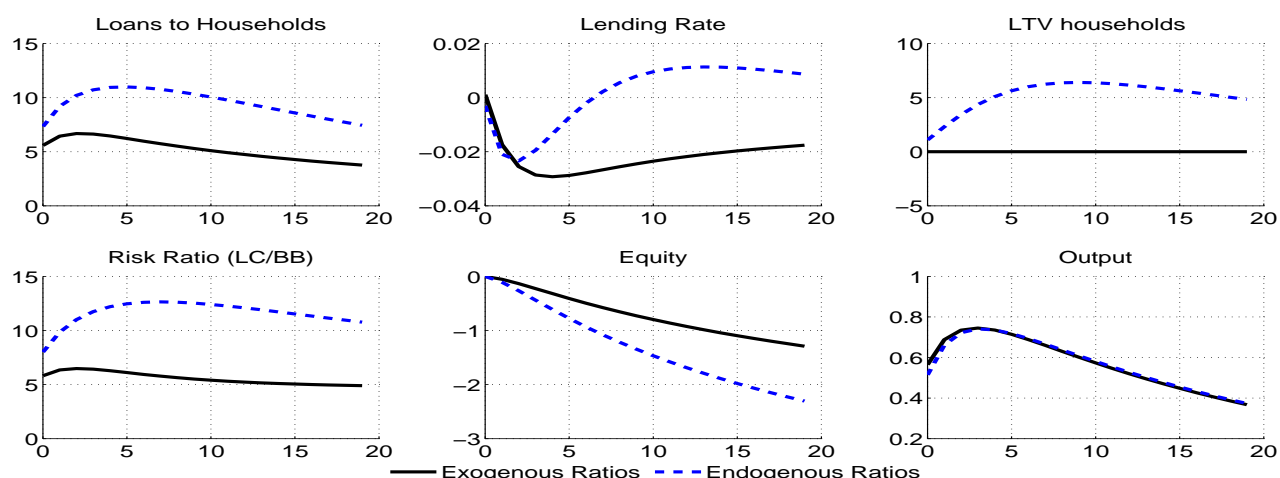

Figure 5: Impulse response functions to a government spending shock
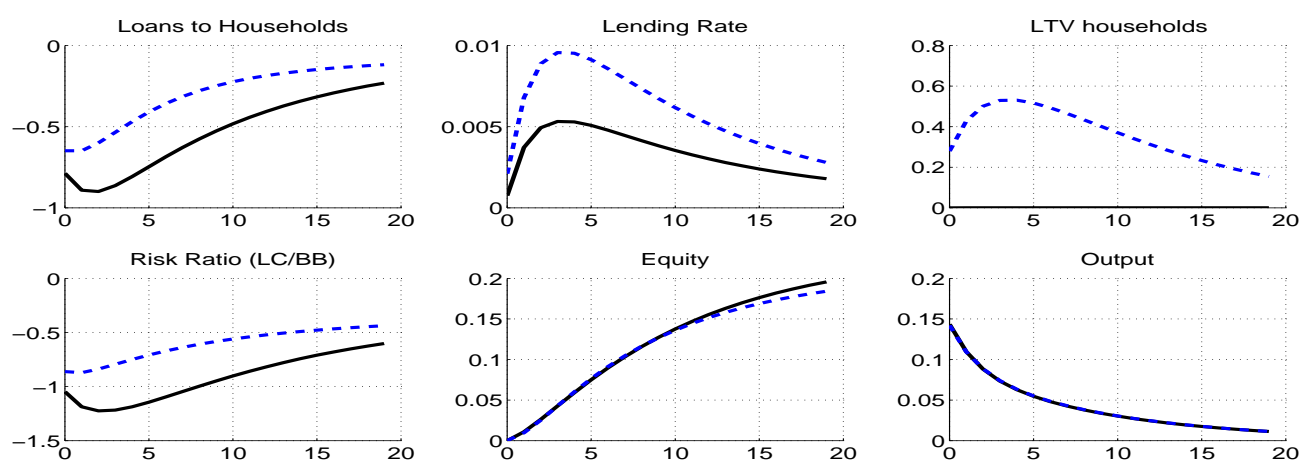

Figure 6: Impulse response functions to a contractionary monetary policy shock
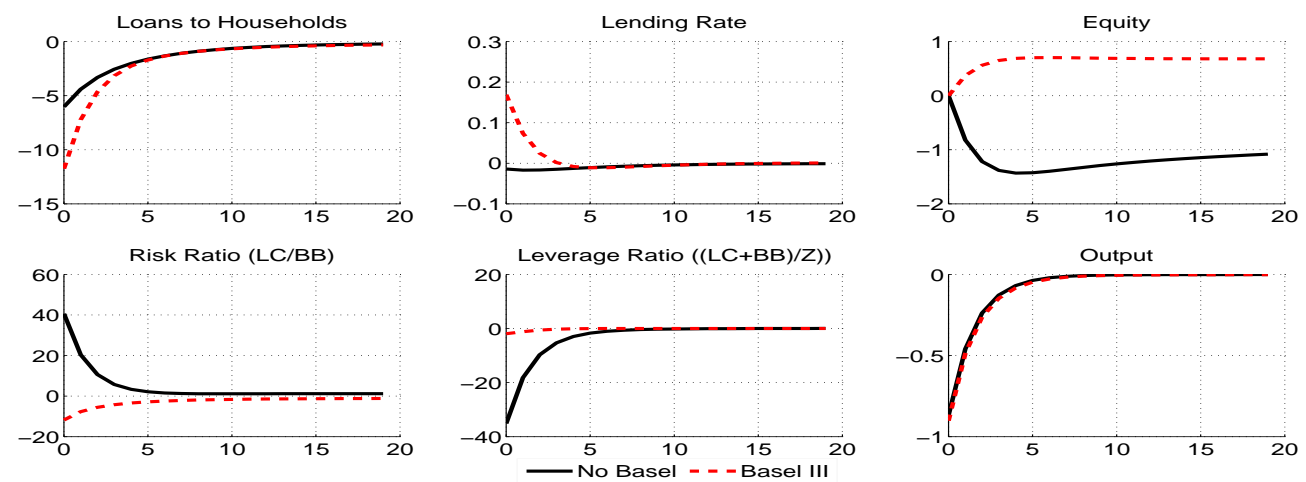
Figure 7: Impulse response functions to a positive technology shock
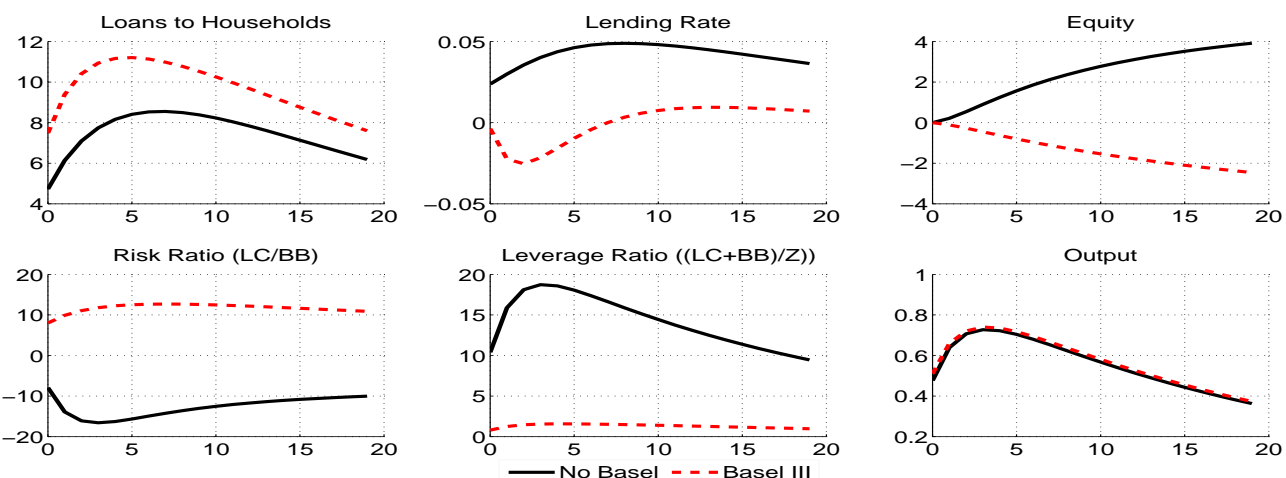

Figure 8: Impulse response functions to a government spending shock
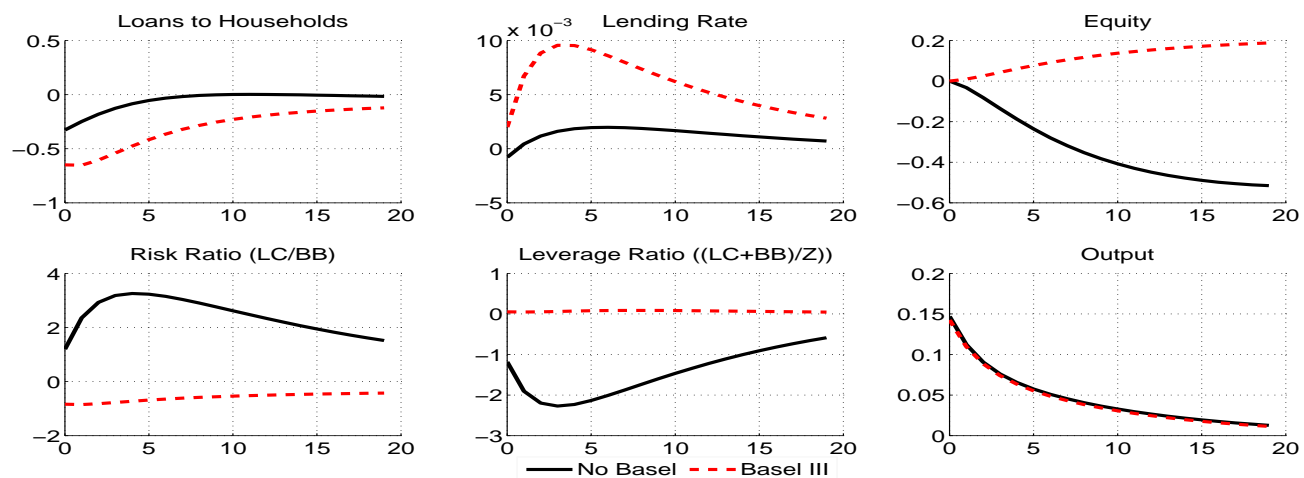

Figure 9: Impulse response functions to a credit crunch shock
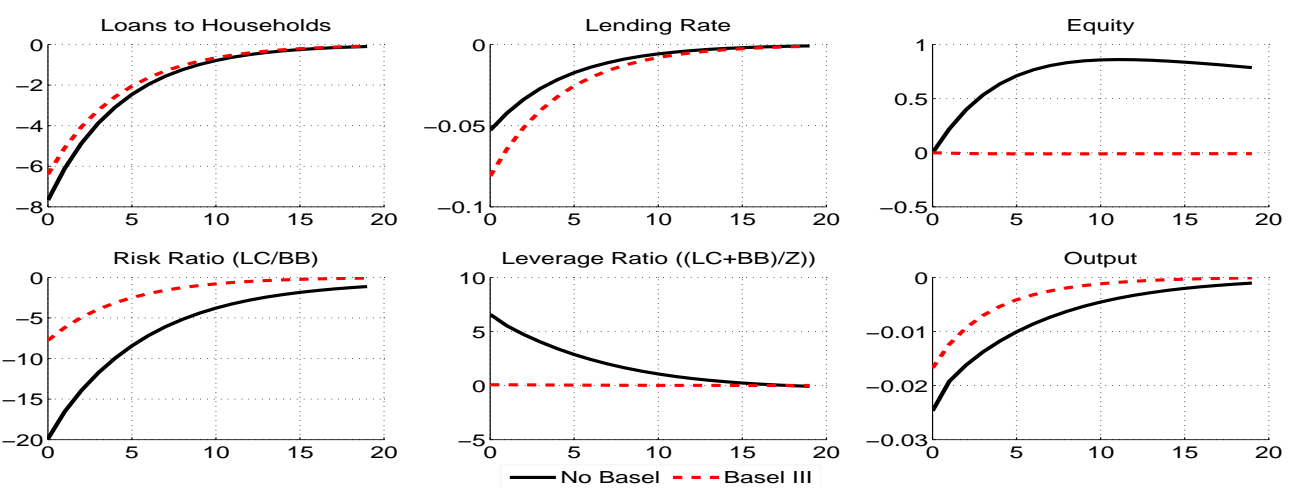

Figure 10: Impulse response functions to negative housing price shock
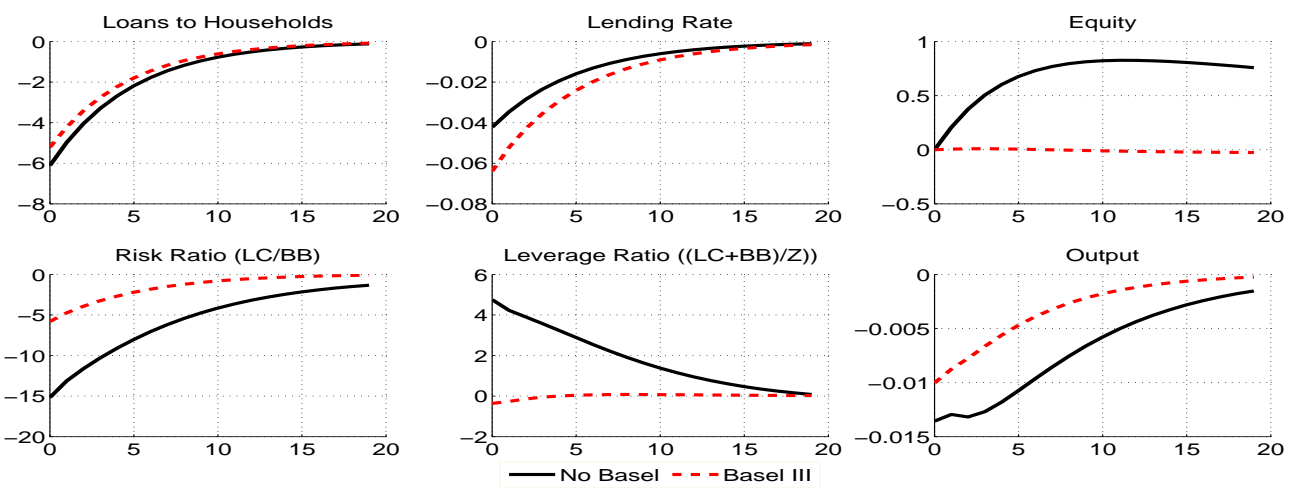
Figure 11: Impulse response functions to a contractionary monetary policy shock
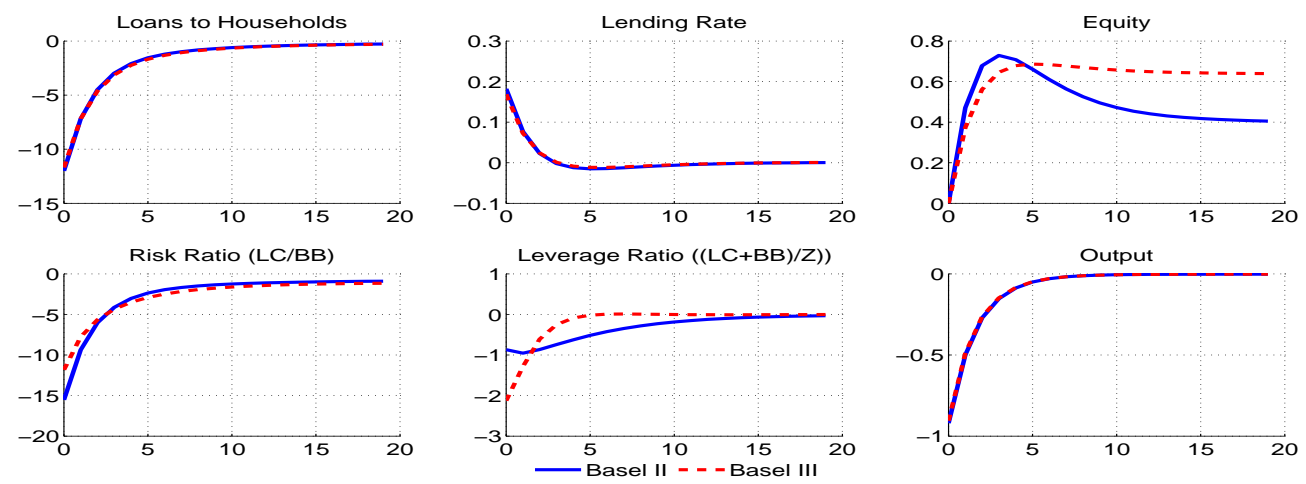

Figure 12: Impulse response functions to a positive technology shock
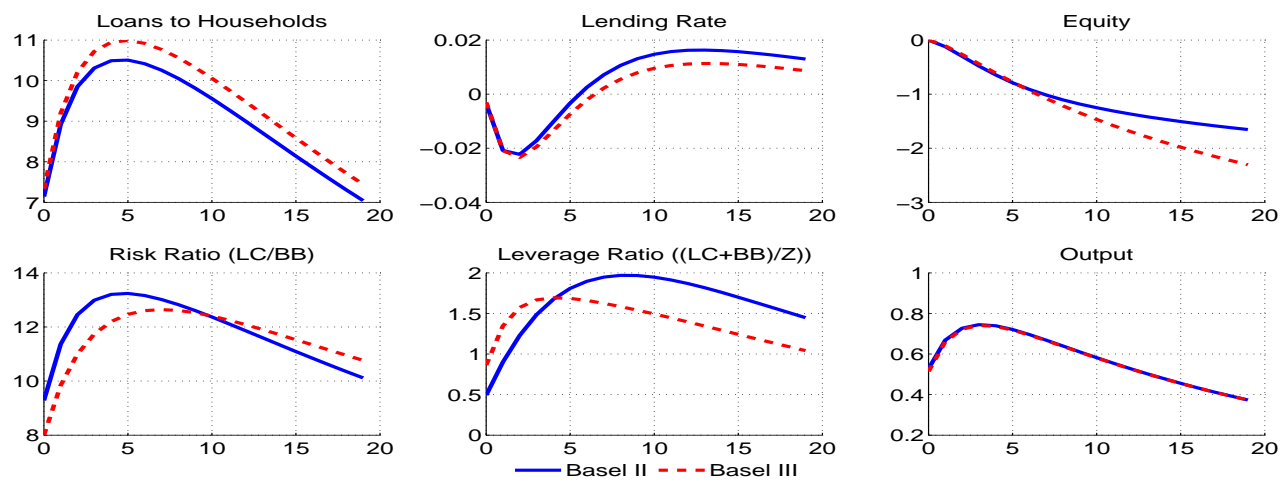

Figure 13: Impulse response functions to a government spending shock
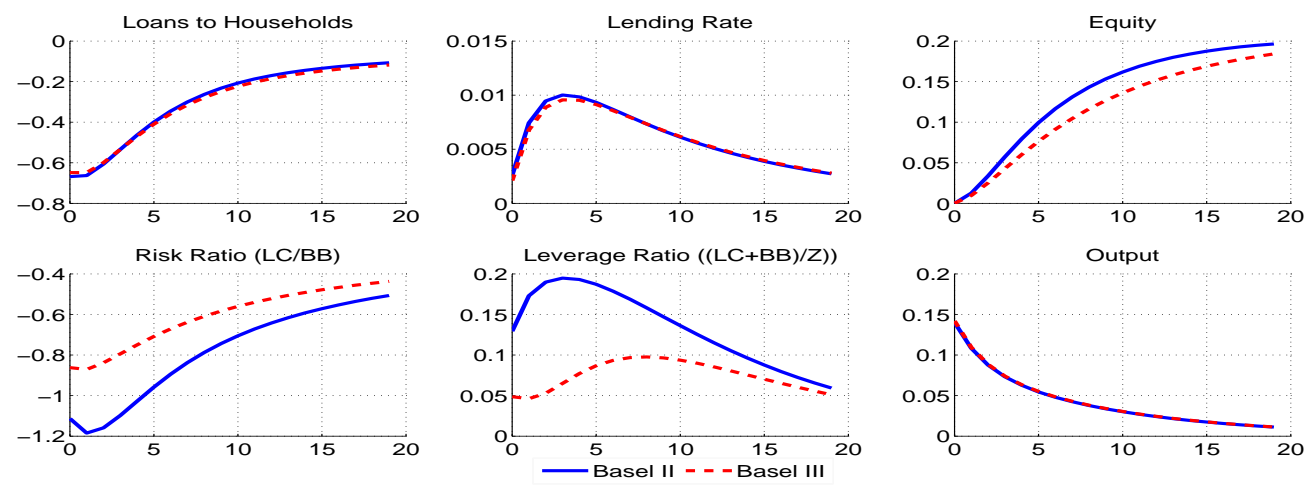


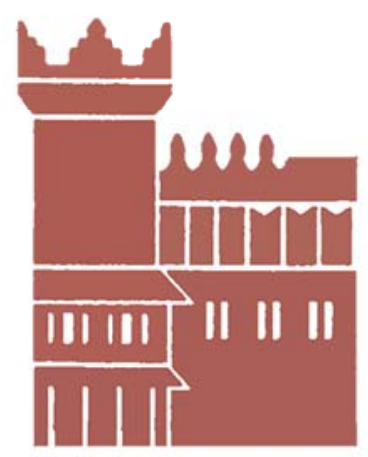

Alma Mater Studiorum - Università di Bologna DEPARTMENT OF ECONOMICS

Strada Maggiore 45

40125 Bologna - Italy

Tel. +39051 2092604

Fax +390512092664

http://www.dse.unibo.it 